Trinity University

Digital Commons @ Trinity

Geosciences Faculty Research

Geosciences Department

1997

\title{
Petrogenesis of Mid-Proterozoic Granitic Magmas: Examples from Central and West Texas
}

Diane R. Smith

Trinity University, dsmith@trinity.edu

C. Barnes

W. Shannon

R. Roback

E. James

Follow this and additional works at: https://digitalcommons.trinity.edu/geo_faculty

Part of the Earth Sciences Commons

\section{Repository Citation}

Smith, D.R., Barnes, C.G., Shannon, W., Roback, R., \& James, E. (1997) Petrogenesis of mid-Proterozoic granitic magmas: Examples from central and west Texas. Precambrian Research, 85(1-2), 53-79. doi:10.1016/S0301-9268(97)00032-6

This Post-Print is brought to you for free and open access by the Geosciences Department at Digital Commons @ Trinity. It has been accepted for inclusion in Geosciences Faculty Research by an authorized administrator of Digital Commons @ Trinity. For more information, please contact jcostanz@trinity.edu. 


\title{
Petrogenesis of Mid-Proterozoic granitic magmas: examples from central and west Texas
}

\author{
Diane R. Smith a, ${ }^{*}$, Calvin Barnes ${ }^{b}$, William Shannon b,1, Robert Roback ${ }^{c, 2}$, Eric James ${ }^{c}$ \\ a Department of Geosciences, Trinity University, 715 Stadium Drive, San Antonio, TX 78212-7260, USA \\ b Department of Geosciences, Box 41053, Texas Tech University, Lubbock, TX, 79409-1053, USA \\ c Department of Geological Sciences, The University of Texas at Austin, Austin, TX, 78712-1101, USA
}

\begin{abstract}
Circa 1.1 Ga granitic magmatism in Texas was manifested as two compositional groups: (1) the 1.12 Ga Red Bluff granitic suite in west Texas; and (2) 1.12-1.07 Ga granites of the Llano uplift of central Texas. Both suites share some characteristics typical of 'anorogenic' granites (e.g. potassium- and iron-rich bulk compositions, Fe-rich hydrous silicates, emplacement conditions involving low oxygen fugacities and water contents) and exhibit similar isotopic characteristics. However, rock associations, mineral chemistries, and trace element compositions of the two suites are distinct and no single petrogenetic model for the two suites is possible.
\end{abstract}

The Red Bluff granitic suite includes cogenetic syenites, quartz syenites and granites; transitional ferrobasaltic dikes are also present. In contrast, syenitic and mafic rocks are not associated with the Llano granites. The Llano granites contain biotite and calcic amphibole with lower $\mathrm{Fe} /(\mathrm{Fe}+\mathrm{Mg})$ ratios compared to those occurring in the Red Bluff rocks. Alkali amphiboles (e.g. arfvedsonite) occur in the Red Bluff granites but not in the Llano granites. The Red Bluff granitoids are characterized by high $\mathrm{FeO}^{\mathrm{T}} / \mathrm{MgO}$ ratios, high $\left(\mathrm{Na}_{2} \mathrm{O}+\mathrm{K}_{2} \mathrm{O}\right)$, high concentrations of HFSE and rare earth elements (REE), and other features typical of A-type, 'within-plate' granites [e.g. the Pikes Peak batholith (PPB)]. The Llano granites are geochemically distinct with generally higher $\mathrm{P}_{2} \mathrm{O}_{5}$ and $\mathrm{Sr}$, lower $\mathrm{Na}_{2} \mathrm{O}$, $\mathrm{FeO}^{\mathrm{T}} / \mathrm{MgO}, \mathrm{Zr}$, Y and $\mathrm{REE}$, and much lower $\mathrm{Ta}$ and $\mathrm{Nb}$. Nd isotopic data overlap between the two granite suites and have 'juvenile' signatures. However, trace element data suggest different petrogeneses for the two suites. The Red Bluff suite is interpreted as having a direct derivation from mantle sources via extended fractional crystallization of basaltic parental magmas, with minor crustal assimilation. The Llano granites appear to represent anatectic melts derived from slightly older, juvenile crustal sources; some melts underwent fractional crystallization controlled by feldspar and accessory minerals.

The petrology and geochemistry of $\sim 1.1$ Ga granites in Texas indicate that they should not be considered as part of a single 'anorogenic' magmatic event. The Red Bluff granitic suite was emplaced into a shelf sequence, north of the Grenville Front, within a broad zone characterized by mild extension. In contrast, Llano granites are late-stage intrusions emplaced into multiply deformed and metamorphosed crust, south of the Grenville Front, during or after waning stages of Grenville orogenesis. 
Keywords: Geochemistry; Granite; Proterozoic; Texas

*Corresponding author. Fax: 001210736 8264; e-mail: dsmith@trinity.edu

1Present address: 9180 Coors Road NW, Apt. 3606, Albuquerque, NM 87120, U.S.A.

2Present address: Mailstop J-514, Los Alamos National Laboratory, P.O. Box 1663, Los

Alamos, NM 87545, USA.

\section{Introduction}

Middle Proterozoic granitic magmatism in Texas occurred in the 1.07-1.12 Ga age range on both sides of the Llano Front (Fig. 1). In west Texas, the $\sim 12 \mathrm{Ga}$ (U-Pb age; Bickford et al., 1995) Red Bluff granitic suite, exposed in the Franklin Mountains, was emplaced into rocks north of the Llano Front. In the Llano uplift, 1.07-1.12 Ga granites intrude rocks of the Grenville Province south of the Llano Front (Walker, 1992).

Previous studies (e.g. Anderson and Bender, 1989; Nelson and DePaolo, 1985) commonly interpreted the Texas Proterozoic granitic suites to be compositionally similar and to share a single tectonic environment. Anderson (1983) included them as part of an 'anorogenic' magmatic pulse that occurred $\sim 1.1 \mathrm{Ga}$ ago in North America. Isotopic data (Table 1) exhibit few differences between the two suites and suggest a common origin. Unfortunately, the data do not clearly distinguish between mantle or crustal sources. For example, Patchett and Ruiz (1989) found that $\mathrm{Nd}$ isotopic data for these granites can be interpreted as documenting either:

(1) addition of older crustal material to magmas derived from depleted mantle reservoirs; or

(2) an anatectic origin involving older, crustal sources whose isotopic signatures did not have sufficient time to evolve to values distinct from depleted mantle signatures.

Our petrological studies show that the west Texas and Llano granites are quite distinct in terms of associated rock types, mineralogy and trace element compositions, and are thus unlikely to share a common origin or uniform tectonic environment. In this paper, we document the petrologic and geochemical characteristics, and address the petrogeneses and tectonic settings of these two rock suites.

\section{Regional geology and tectonic setting}

Basement rocks of Texas are bisected by the Llano Front (Fig. 1), which separates undeformed rocks to the north from rocks to the south which were deformed and metamorphosed in Grenville time ( 1.1-1.3 Ga). The Precambrian basement north of the Front is dominated by granitic and rhyolitic rocks of the 1.35-1.5 Ga Granite-Rhyolite Province (Thomas et al., 1984), adjacent to older rocks of the Yavapai-Mazatzal Province (Nelson and DePaolo, 1985). In Texas and New Mexico, rocks of the Granite-Rhyolite Province are locally overlain by undeformed shelf carbonates and clastic rocks that are intercalated with mafic to intermediate volcanic rocks (e.g. Denison et al., 1984). 
The Texas Grenville Province consists of polydeformed gneiss, schist and amphibolite, with sparse metaserpentinite and local eclogite occurrences (e.g. Mosher, 1993). U-Pb zircon ages of orthogneiss in the Llano uplift range from 1.22 to $1.35 \mathrm{Ga}$ (Mosher, 1993). Grenville rocks exposed in west Texas are older than 1.35 Ga (Bickford et al., 1995; K. Nielsen, personal communication, 1994).

Circa 1.1 Ga felsic igneous rocks are present on both sides of the Grenville Front. In the Franklin Mountains of west Texas (Fig. 1), undeformed 1.25 Ga sedimentary rocks (Pittenger et al., 1994) are overlain by trachytic to rhyolitic lavas and ignimbrites, all of which are presumed to overlie Yavapai-Mazatzal basement rocks. The entire section was intruded by the 1.12 Ga Red Bluff Granitic Suite [RBG; Fig. 2; Shannon et al. (1997)]. Similar granitic and rhyolitic rocks are exposed in scattered outcrops as much as $120 \mathrm{~km}$ east of the Franklin Mountains (e.g. Denison et al., 1984). In the Llano uplift (Figs. 1 and 3), numerous ovoid, mostly coarse-grained, granitic plutons were emplaced into polydeformed and polymetamorphosed igneous and sedimentary rocks over a span of time from 1.12 to 1.07 Ga [U-Pb ages; Walker (1992); Roback (1996)]. Emplacement was probably at shallow crustal levels, although coeval volcanic rocks are not preserved. These plutons are typically undeformed but some bodies exhibit evidence for deformation during and after magma emplacement (Reed, 1995).

Elsewhere in the western U.S., another example of, $\sim 1.1$ anorogenic granitic plutonismand one of the classic examples of 'A-type' granitic magmatism-is the PPB of central Colorado (PPB; Figs. 1 and 4). This composite intrusion was emplaced $\sim 1.08 \mathrm{Ga}$ ago [U-Pb age; D. Unruh, personal communication (1992)] into host rocks comprised of the $\sim 1.7 \mathrm{Ga}$ synorogenic Boulder Creek grano-diorite and related gneisses and the $\sim 1.4$ Ga anorogenic Silver Plume granite (Wobus and Hutchinson, 1988).

Mafic magmatism, contemporaneous with the granites examined here, occurred in some North American localities at $\sim 1.1 \mathrm{Ga}$, the most voluminous example is that associated with the Mid-Continent Rift (e.g. Paces and Bell, 1989; Van Schmus and Hinze, 1993). At approximately the same time, the 1.16-1.07 Ga Pecos mafic intrusive complex was emplaced in west Texas [Fig. 1; Keller et al. (1989)]. This subsurface complex consists of four distinct lobate units that range from 3 to $10 \mathrm{~km}$ thick (Adams and Miller, 1995). Well cuttings (Kargi and Barnes, 1995) and seismic data (Adams and Miller, 1995) show the largest unit to be a layered mafic to ultramafic body. Basaltic magmatism at 1.1 Ga was also widespread in the southwestern U.S. (Fig. 1), where rocks of the Yavapai-Mazatzal Province were cut by numerous diabasic dikes and sills (Hammond, 1986). These dikes have been interpreted to indicate that much of southwestern U.S. was in an extensional tectonic environment during this time [Hammond (1986); but see Howard (1991)].

\subsection{Summary of tectonic setting}

Emplacement of the rift-related Pecos intrusive complex and widespread diabasic dike injection in the southwest suggest that west Texas north of the Grenville Front experienced extensional tectonic stresses during emplacement of the RBG. Late stage ferrobasaltic dikes in the RBG are steeply dipping, and support emplacement in an extensional realm. It is 
certainly clear that extension dominated the mid-continent region at this time. The tectonic setting of the Llano uplift during $\sim 1.1 \mathrm{Ga}$ granitic magmatism is uncertain. Syn-magmatic deformation within some of the plutons suggests that magmatism accompanied waning stages of Grenville deformation, but other plutons appear undeformed. Details of the timing and cause of deformation and magmatism are yet to be resolved.

\section{Enchanted rock batholith (ERB)}

The 1.08 Ga [U-Pb age; Walker (1992)] Enchanted Rock batholith (ERB; Fig. 3) is the best characterized post-tectonic pluton in the Llano uplift and is a representative example of granitic magmatism of the time and region; we thus focus on this pluton here. Earlier studies documented a generally reverse concentric zonation in this and other Llano plutons (Keppel, 1940; Hutchinson, 1956). Hutchinson (1956) documented compositions in the ERB ranging from coarse-grained granite, granodiorite and quartz monzonite in the outer and intermediate zones, grouped together here as the outer zone, to fine- to mediumgrained quartz monzonite and leuco-granite in the inner zone. Intermediate rock types are rare, and, in contrast to the RBG (and sodic series of the PPB, see below), the Llano granitic suite is not associated with coeval mafic or syenitic rocks.

Most ERB samples are metaluminous but a few are slightly peraluminous. Outer zone rocks are two-feldspar porphyritic granites with megacrystic alkali feldspar and local rapakivi texture. Fe-rich biotite is present in both zones; calcic amphibole in amounts $>1 \%$ is present only in portions of the outer zone. Accessory minerals consist of magnetite, sphene, zircon, apatite, allanite and fluorite.

Hutchinson (1956) also mapped the occurrence of fine-grained, dark colored inclusions which he interpreted as solid fragments of country rock (i.e. as xenoliths). Based on field, petrographic and mineralogical evidence, Smith and Wark (1992) interpreted these inclusions as microgranular magmatic enclaves, that is, globules of hybridized magma injected into and quenched by the host granite while it was still in a partially molten state. The enclaves are metaluminous and have slightly lower silica contents compared to the host granites, thus they are not truly mafic (basaltic) in composition. They contain alkali feldspar and amphibole 'xenocrysts' (from the host granite) and plagioclase and quartz phenocrysts in a fine groundmass.

\section{The RBG suite}

The RBG was emplaced in five stages, as sketched in Fig. 2. The first stage consists of sills of porphyritic alkali feldspar granite, which, in the thickest sills, grades inward to cumulate alkali feldspar quartz syenite. The second, most voluminous stage consists of coarsegrained alkali-feldspar granite. The third stage is alkali feldspar quartz syenite and the fourth stage consists of small intrusions of alkali feldspar leucogranite. This latter stage cuts volcanic rocks associated with Red Bluff magmatism. The fifth stage consists of arfvedsonite granite dikes. Rough estimates of the relative exposed volumes of the RBG stages are as follows: stage 1, 5-10\%; stage 2, 80-90\%; stage 3, <3\%; stage $4,<5 \%$; stage 5 , 
$<2 \%$. Ferrobasaltic dikes are also present in the RBG; they are generally the latest intrusions, but some are cut by stage 4 and 5 dikes.

Stages 1-4 are metaluminous. The common ferromagnesian silicates are ferroedenite and annite. Ferrohedenbergite is present in rocks of stages 1 and 3, and grunerite pseudomorphs after fayalite(?) are present in stages 2 and 3 . Annite is the only mafic phase in stage 4. Accessory minerals consist of zircon, apatite, ilmenite, fluorite and sparse magnetite. Rocks from stage 5 are peralkaline; arfvedsonite is the common mafic mineral and astrophyllite is locally present. Zircon and fluorite are the accessory minerals. Alkali feldspars in rocks from all stages are typically exsolved, but 'integrated' compositions range from $\mathrm{Or}_{58}$ to $\mathrm{Or}_{75}$. Plagioclase $\left(\sim \mathrm{An}_{25}\right)$ is rarely present as cores of alkali feldspar from stage 3 .

\section{Pikes peak batholith}

The PPB is an immense composite batholith with a total surface exposure of $\sim 3840 \mathrm{~km}^{2}$ (Fig. 4). The major volume of the batholith is coarse biotite/hornblende granite and granodiorite which were intruded by late-stage alkalic plutons. The late-stage plutons form $10 \%$ of the exposed PPB and are located within and marginal to the main stage of the batholith. They include two chemical series, one with a potassic trend, dominantly granitic and the other with a sodic trend, dominantly syenitic (Barker et al., 1975; Wobus, 1976; Wobus and Anderson, 1978). Rocks of the sodic series include syenite, quartz syenite and fayalite- and sodic amphibole-bearing granites; minor gabbro is also present. The syenites are peralkaline whereas the granites are peraluminous to metaluminous. Mafic mineral assemblages are variable and commonly include iron-rich calcic and sodic amphiboles, annite, fayalite and hedenbergite; astrophyllite is present locally. Accessory minerals consist of variable amounts of zircon, fluorite, $\mathrm{Fe}-\mathrm{Ti}$ oxides and allanite/chevkinite.

The sodic series plutons exhibit features typical of A-type granites and striking similarities with the RBG, and we use them as a basis for comparison with the $1.1 \mathrm{Ga}$ granites of Texas. Note that subsequent discussion and illustrations in this paper include data for only the Pikes Peak late sodic plutons, and not for the late potassic plutons, nor for coarse-grained granites and granodiorites comprising the major volume of the batholith.

\section{Mineral chemistry}

Representative analyses of biotites and amphiboles in the PPB are given in Barker et al. (1975) and Giambalvo (1993). Shannon et al. (1997) give representative analyses of biotites and amphiboles occurring in the RBG. Tables 2 and 3 give representative analyses of biotite and amphibole, respectively, in the ERB. In all three suites, these minerals are iron-rich, similar to those occurring in typical anorogenic granites as defined by Anderson (1983). 


\subsection{Biotite}

Micas in the sodic PPB and RBG are annites (Fig. 5), whereas the ERB micas show lower values of $\mathrm{Fe} /(\mathrm{Fe}+\mathrm{Mg})$. In both suites, $\mathrm{Fe} /(\mathrm{Fe}+\mathrm{Mg})$ in biotite correlates with whole-rock $\mathrm{Fe} /(\mathrm{Fe}+\mathrm{Mg})$. Biotites in the outer and inner zones of the ERB have distinct compositions. Compositions of biotites in ERB enclaves correlate with location within the enclave such that biotites from enclave margins overlap in composition with those from the host granite, whereas those in enclave interiors have lower $\mathrm{Fe} /(\mathrm{Fe}+\mathrm{Mg})$.

\subsection{Amphibole}

Calcic amphiboles in the sodic PPB and RBG are predominantly edenite and edenitic hornblende (Fig. 6a), whereas they are predominantly hastingsite and hastingsitic hornblende in the ERB. The ERB lacks the low-calcium amphiboles found in the sodic PPB and RBG suites, both of which include arfvedsonite; richterite is also present in the sodic PPB (Fig. 6b).

ERB amphiboles show lower values of $\mathrm{Fe} /(\mathrm{Fe}+\mathrm{Mg})$ than either the $\mathrm{RBG}$ or sodic PPB (Fig. 7), which is consistent with whole-rock Fe/(Fe+Mg) values (see Fig.8). Calculated $\mathrm{Fe}^{+3} / \mathrm{Fe}^{+2}$ ratios [after the method of Cosca et al. (1991)] are generally low in all three suites (Fig. 7a), but $\mathrm{Fe}^{3+} / \mathrm{Fe}^{2+}$ ratios in ERB granites are slightly higher compared to calcic amphiboles in the main volume of the RBG. Late-crystallizing arfvedsonites from stage 5 of the $\mathrm{RBG}$ have the highest $\mathrm{Fe}^{3+} / \mathrm{Fe}^{2+}$ ratios, which apparently reflect the incompatible behavior of $\mathrm{Fe}^{3+}$ during late-stage crystallization.

Fluorine contents of ERB and RBG calcic amphiboles are comparable (Fig. 7b) and lower than arfvedsonite from stage 5 of the RBG where fluorine contents are high and variable. High whole-rock fluorine contents are typical of stage 5 arfvedsonite granites (Shannon, 1994 ). It is noteworthy that the fluorine contents in biotites of the RBG are lower than in the amphiboles. This effect probably results from the sequence of crystallization: amphibole crystallization preceded late-stage co-precipitation of fluorite + biotite. Thus fluorine was enriched in the melt during early amphibole crystallization, but during biotite crystallization, fluorine was depleted by fluorite crystallization (Shannon, 1994; Shannon et al., 1997).

\section{Conditions of crystallization}

Shannon et al. (1997) calculated temperatures with the zircon saturation thermometer (Watson and Harrison, 1983) that range from 1057 to $727^{\circ} \mathrm{C}$ for the RBG. Although inherited zircon in granitic rocks can lead to extremely high concentrations of $\mathrm{Zr}$ and erroneously high temperature estimates, there is no $\mathrm{Pb}$ isotopic evidence for inherited zircon in the RBG (Wasserburg et al., 1962; Copeland and Bowring, 1988; Roths, 1993; Shannon et al., 1997). Furthermore, syenitic dikes of stage 3 contain zircon microphenocrysts and acicular zircon; the high $\mathrm{Zr}$ contents in these rocks are not the result of zircon accumulation. The ERB contains euhedral zircon and, similar to the RBG, there is no evidence for inherited zircon (Walker, 1992). Temperatures for the ERB based on zircon 
saturation and plagioclase-hornblende thermometry (Blundy and Holland, 1990) mostly fall in the range of $750-830^{\circ} \mathrm{C}$. For the sodic PPB, Saltoun (1993) estimated zircon saturation temperatures for the fayalite-bearing granitoids that range from 865 to $966^{\circ} \mathrm{C}$, and Beane (1993) estimated apatite saturation temperatures (Harrison and Watson, 1984) for syenites that range from 724 to $961^{\circ} \mathrm{C}$.

The RBG and fayalite-bearing granites of the sodic PPB apparently crystallized at low oxygen fugacities (Shannon et al., 1997; Barker et al., 1975). The low $\mathrm{Fe}^{3+} / \mathrm{Fe}^{+2}$ values of the RBG and sodic PPB calcic amphiboles agree with estimated $\mathrm{fO}_{2}$, at or below the quartzfayalite-magnetite (QFM) buffer. Although the ERB contains magnetite, the high $\mathrm{Fe} / \mathrm{Mg}$ in biotite reflects crystallization at relatively low oxygen fugacities, below QFM (Anderson and Smith, 1995).

Normative Qz-An-Or relations show that all three suites do not plot along minimum-melt compositions characteristic of water-saturated granites, but rather towards the Or apex. Most compositions cluster at $a_{\mathrm{H}_{2} \mathrm{O}}$ between 0.3 and 0.5 (Ebadi and Johannes, 1991), indicating that the magmas were characterized by water-poor conditions. Other features of the granitic suites-for example, general paucity of pegmatites, late crystallization of hydrous phases, relatively shallow levels of emplacement and high temperatures of crystallization - are also consistent with $P_{\mathrm{H}_{2} \mathrm{O}}<P_{\text {total }}$.

In summary, temperatures for the ERB ranged from $\sim 750$ to $830^{\circ} \mathrm{C}$, and the highest temperatures are found for the RBG and sadie PPB (up to $\sim 950-1000^{\circ} \mathrm{C}$ ). All three seem to have crystallized under conditions of low water contents and oxygen fugacities.

\section{Whole-rock geochemistry}

Representative chemical analyses for the RBG, sodic PPB and ERB rocks are given in Tables 4-7. Additional analyses for the RBG can be found in Shannon et al. (1997). Barker et al. (1975, 1976), Wobus (1976), Wobus and Anderson (1978), Beane (1993), Saltoun (1993) and Kay (1993) give further analyses for the PPB. Additional analyses chemistry, the RBG, ERB and PPB granitic suites for the ERB and PPB can be requested from the first author.

On the basis of mineralogy and major element chemistry, the RGB, ERB and PPB granitic suites have been broadly classified as anorogenic (e.g. Anderson and Bender, 1989). Potassium contents and $\mathrm{Fe} /(\mathrm{Fe}+\mathrm{Mg})$ ratios are high in all three suites relative to synorogenic granites, but the RBG and sodic PPB area characterized by extremely high values of $\mathrm{Fe} /(\mathrm{Fe}+\mathrm{Mg}$ ) (Fig. 8a).

In contrast, the three suites exhibit distinctions in their trace element chemistry. For example, very low Sr contents characterize the RBG and sodic PPB, with higher values found for the ERB (Fig. 8b). The RBG and sodic PPB suites have geochemical features typical of A-type or within-plate granites, however, this classification for the ERB is not clear. The Ga/Al ratio of the ERB granites (Fig. 9) is considerably lower than that of the RBG and PPB sodic series and plots predominantly in the field of I-, S- and M-types. In terms of 
the alkali/lime ratio and HFSE concentrations (Fig. 10), the ERB compositions straddle the boundary between granite types, whereas the RBG and PPB sodic series are clearly A-type (Fig. 11). Similarly, the RBG and PPB display geochemical features (e.g. high Nb and Y contents, Fig. 12) commonly associated with 'within-plate' granites whereas the ERB exhibits features which overlap with granites emplaced in several tectonic settings.

Rare earth element (REE) patterns for the dominant volumes of these three systems are generally similar in shape (Fig. 13). REE abundances of stages 1, 2 and 3 of the RBG are generally within the range of the PPB sodic series, but the RBG patterns display a slightly shallower slope than the PPB. For the RBG, REE abundances generally increase with increasing $\mathrm{SiO}_{2}$ from syenite to alkali feldspar granite (stage 3 to stage 2), then decrease with further differentiation (from stage 2 to stage 4 leucogranites). Stage 5 arfvedsonite granites display a wide range of REE abundances which are typically higher than the rest of the RGB. The REE patterns of the ERB, although similar in shape to the PPB, have lower abundances of all but the heavy REE and have smaller Eu anomalies (Fig. 13). In addition, REE abundances decrease from the outer to the inner zones.

$\mathrm{Pb}$ and $\mathrm{Sm}-\mathrm{Nd}$ analyses of samples from the ERB and the RBG are presented in Tables 1 and 8 and illustrated in Figs. 13 and 14. Pb isotopic analyses of whole rock and feldspar from both the ERB and RBG define an linear array on an ${ }^{207} \mathrm{~Pb} /{ }^{204} \mathrm{~Pb}$ versus ${ }^{206} \mathrm{~Pb} /{ }^{204} \mathrm{~Pb}$ plot, the slope of which approximates the $1.1 \mathrm{Ga}$ age of the rocks. Initial Pb values, as approximated by feldspar analyses, are similar to $1.0 \mathrm{Ga}$ model mantle (Zartman and Doe, 1981). The spread of ${ }^{208} \mathrm{~Pb} /{ }^{204} \mathrm{~Pb}$ versus ${ }^{206} \mathrm{~Pb} /{ }^{204} \mathrm{~Pb}$ suggests average crustal Th/U ratios. Epsilon $\mathrm{Nd}$ at emplacement $(1.08 \mathrm{Ga})$ ranges from +2.7 to +4.3 for the ERB (Fig. 14), corresponding to depleted mantle model ages 100-200 million years older than the emplacement age. Epsilon $\mathrm{Nd}$ at emplacement $(1.12 \mathrm{Ga})$ for granitic and syenitic rocks from the RBG [Fig. 14; data from Patchett and Ruiz (1989)] ranges from +2.4 to +3.7 , corresponding to depleted mantle model ages 170-230 million years older than emplacement age. The isotopic data for the ERB and RBG suggest either: (1) depleted mantle sources; or (2) crustal sources recently derived from mantle.

\section{Petrogenetic models}

\section{1. $E R B$}

There are very few intermediate and virtually no mafic rocks associated with the Llano high-K granites. In general, granite plutons of the Llano uplift are remarkably homogeneous with respect to major elements [Barker, p. 40, in Mosher (1996)], especially when data for magmatic enclaves are excluded from calculated averages. The large volume of granite in the uplift [45\% of the exposed area; Johnson et al. (1976)] and the lack of associated mafic rocks suggest that the granites represent anatectic melts derived from crustal sources. Melting of crustal basement rocks could explain the region-wide homogeneity of the Llano granites, in contrast to the extended compositional ranges exhibited by the sodic PPB and RBG. 
If crustal sources are assumed, partial melting of tonalitic/granodioritic crust could yield the high- $\mathrm{K}_{2} \mathrm{O}$ calc-alkaline magmas (Roberts and Clemens, 1993) that characterize the ERB. Such a source is supported by experimental studies (e.g. Skjerlie and Johnston, 1993). Major element compositions of ERB rocks are very similar to melts produced in vaporabsent experiments, whereas poorer matches are found between ERB compositions and melts produced in vapor-present experiments (Carroll and Wyllie, 1990).

Crustal wall rocks to the ERB and similar coeval granite plutons in the Llano uplift include $\sim 1.25$ Ga tectonized granitic rocks (Valley Spring Gneiss, Lost Creek Gneiss, orthogneiss within the Packsaddle Schist) and the Coal Creek Domain, an island arc terrane that evolved separately from, and later collided with, the rest of the Llano uplift (Roback et al., 1995). Rocks of the Coal Creek Domain have $\mathrm{Pb}$ and $\mathrm{Nd}$ isotopic characteristics distinct from the ERB (Figs. 13 and 14) and thus could not have been significant magma sources for the ERB. The ERB has Ph isotopic characteristics similar to the Valley Spring Gneiss and Packsaddle orthogneiss (Fig. 13), and Nd isotopes (Fig. 14) also suggest the $\sim 1.25 \mathrm{Ga}$ tectonized granitic rocks as possible source rocks. However, the Valley Spring Gneiss has ${ }^{87} \mathrm{Sr} /{ }^{86} \mathrm{Sr}$ at $\sim 1.1 \mathrm{Ga}$ of $\sim 0.7105$, in contrast to $\sim 0.7048$ for the ERB (Garrison et al., 1979), indicating that ERB magmas could not have been derived from partial melting of Valley Spring Gneiss (Barker et al., 1995). Oxygen isotope data are not available for the ERB, but relatively high $\delta^{18} 0$ values [+ 9.3 to $+9.7 \%$; Bebout and Carlson (1986)] for other coeval granitic rocks in the Llano uplift seemingly require a significant crustal component.

Trace element models favor tonalitic crustal sources for the ERB. Fig. 15a illustrates ERB compositions for inner and outer zone rocks and trends in $\mathrm{Ba}$ and $\mathrm{Sr}$ during partial melting and fractional crystallization processes. The magmatic enclaves are not included in Fig. 15 because their origin is thought to involve magma mixing/mingling processes (Smith and Wark, 1992), in addition to fractionation and/or source effects. In general, ERB compositions can be produced by $20-30 \%$ melting of a tonalitic source; some outer zone compositions were affected by fractionation dominated by feldspar removal/accumulation. Other geochemical data are consistent with emplacement of at least two magma types in the outer and inner zones. Samples at similar stages of evolution (e.g. similar $\mathrm{SiO}_{2} \mathrm{wt} \%$ or $\mathrm{Eu} / \mathrm{Eu}^{*}$ ) but from the two different zones exhibit geochemical differences (e.g. $\mathrm{Fe} /(\mathrm{Fe}+\mathrm{Mg}$ ) in whole-rock samples and biotites; $\mathrm{Cs}$, Hf and REE abundances in whole-rock samples; $\mathrm{Pb}$ isotopic ratios in feldspars] that indicate they either evolved from distinct parental magmas or experienced different anatectic histories. The differences between outer and inner zone compositions are subtle and can be accounted for by small variations in source composition, which are likely for lower crustal assemblages. However, mafic compositions are not plausible sources for ERB magmas because they yield melts with $\mathrm{Sr}$ and Ba contents significantly higher than ERB magmas (cf Fig. 15a), and with low potassium contents (Roberts and Clemens, 1993) in contrast to the high-K nature of the ERB.

Although the data favor a crustal origin, the presence of magmatic enclaves in the outer zone of the ERB provides evidence for the interaction of intermediate (to mafic?, that is, mantle-derived?), low- $\mathrm{K}_{2} \mathrm{O}$ magmas that were injected into and quenched by the host granite while it was still in a partially molten state (Smith and Wark, 1992). Unfortunately, it cannot be determined whether the mafic endmember magma was mantle-derived basalt 
since the enclaves are interpreted as having undergone magma mixing/mingling processes. Considering the $\mathrm{Nd}$ data, the ERB magmas appear to have a depleted mantle component (cf Fig. 14). If ERB magmas were formed by melting of slightly older crustal rocks derived from depleted mantle (e.g. isotopically similar to the $\sim 1.25$ Ga tectonized granitic rocks) then no mantle component need be involved. However, if melting involved older crust extracted from depleted mantle 1.35 Ga ago (cf Fig. 14), a mantle component appears to be required. Even if granitic rocks of the ERB have no or little mantle material component, we do not rule out the importance of mantle heat input during granitic magma genesis.

\section{2. $R B G$ suite}

Although isotopic data for the ERB and PPB are similar, we interpret the other geochemical and petrologic data as indicative of an origin for the RBG involving fractionation of mantlederived basalt, in contrast to the crustal anatexis model for the ERB. For the RBG, major element mass balance calculations [see Shannon et al. (1997), for details] show that the sequence stage $3 \rightarrow$ stage $2 \rightarrow$ stage 4 represents a plausible fractional crystallization liquid line of descent. Trace element models support these conclusions (Fig. 16a) and indicate that fractionation was inefficient: as much as $40 \%$ melt was trapped among accumulated crystals (Shannon et al., 1997; Shannon, 1994). Fig. 15b also supports a multi-state fractionation history for the RBG, but suggests that the least evolved RBG compositions (i.e. with highest $\mathrm{Sr}$ and $\mathrm{Ba}$ ) are the result of crustal anatexis (similar to the ERB). However, Fig. $16 \mathrm{~b}$ clearly shows that partial melting of tonalitic compositions cannot produce the high $\mathrm{Zr}$ contents which characterize the RBG, nor can it explain compositional trends within the RBG. Partial melting of known or plausible crustal rock types with high Zr contents can generate some RBG samples, but not the elemental abundances nor trends of the RBG as a whole. As previously mentioned, high concentrations of $\mathrm{Zr}$ could be the result of inherited zircon, but petrographic and $\mathrm{Pb}$ isotopic evidence argue against this interpretation (Shannon et al., 1997). Furthermore, inherited zircon does not explain the high contents of other trace elements (REE, Y, Nb, Ta, Hf, Zn, Ga) that characterize RBG rocks.

The isotopic data (Table 1; Figs. 14 and 15) are consistent with petrogenesis of the RBG by extensive fractional crystallization of mantle-derived basaltic parents, as are high temperatures estimated for RBG magmas (up to $1000^{\circ} \mathrm{C}$ ). Oxygen isotopic data indicate that assimilation of crustal rocks (up to 20\%) is also possible (Shannon et al., 1997). This crustal component must be isotopically similar to ca 1.1 Ga depleted mantle. Crustal rocks to the west in the Yavapai-Mazatzal crustal province (Wooden et al., 1988) have distinctive isotopic characteristics that preclude them as source materials for the RBG.

\subsection{PPB sadie suite}

Barker et al. $(1975,1976)$ suggested that the sodic series of the PPB formed by fractional crystallization of mantle-derived alkali basaltic parents coupled with assimilation of deep crustal rocks. Recent isotopic and trace element studies of the PPB (Douglass and Smith, 1993; Sturm et al., 1993) are in agreement with these conclusions. The data thus support a petrogenesis for the sodic series of the PPB similar to that for the RBG. However, the Nd isotopic ratios (Fig. 14) indicate a mantle source that is isotopically distinct from mantle 
presumed to be the source for RBG parental basaltic magmas. The mantle beneath Colorado was evidently affected by an enrichment event, possibly associated with subduction during the $\sim 1.7$ Ga Boulder Creek orogeny, which did not similarly affect the mantle beneath west Texas.

\section{Discussion and conclusions}

Circa 1.1 Ga granitic magmatism in Texas was apparently manifested as two compositional groups. In west Texas, north of the Grenville Front, the Red Bluff granitic suite represents a pulse of highly evolved syenitic and granitic melts emplaced into undeformed rocks. This granitic suite is very similar to the sodic series of the PPB, which is proposed to have a similar petrogenesis. Both plutonic systems were probably emplaced in an extensional tectonic setting; both occupy positions 'inboard' of broadly coeval rift zones.

South of the Grenville Front, in the Llano uplift of central Texas, $\sim 1.1$ Ga granitic magmatism is exemplified by the ERB. The ERB is distinct from both the RBG and PPB in having local rapakivi texture, lower $\mathrm{Fe} /(\mathrm{Fe}+\mathrm{Mg})$, lower concentrations of HFSE, and trace element abundances transitional between A-type and fractionated granites. The range of compositions exhibited by the ERB is smaller compared to those exhibited by the RBG and sodic PPB, especially with regards to several trace elements (cf Figs. 12, 15 and 16). In addition, no mafic or syenitic compositions are associated with the ERB and other coeval Llano granites, and maximum estimated temperatures are significantly lower compared to the RBG (and sodic PPB). The tectonic setting of the ERB is uncertain. Further work is needed to determine the relative timing of and tectonic 'trigger' for $\sim 1.1$ Ga granitic magmatism, final Grenville deformation and juxtaposition of Grenville Province crust with Laurentia.

The Nd isotopic data overlap between the two granite suites and have 'juvenile' signatures similar to those documented for other A-type granites (e.g. Whalen et al., 1996). We caution that if only isotopic data (especially Nd) for the sodic PPB, RBG and Llano suites are examined, one might conclude that the ERB and RBG shared a common petrogenesis that involved a significant depleted mantle component, whereas the sodic PPB had a distinct origin involving crustal materials and/or relatively more enriched mantle sources. We interpret the petrologic, mineralogical and geochemical data in their entirety as more consistent with an indirect derivation from mantle sources for the ERB involving anatexis of tonalitic, juvenile crust (cf Whalen et al., 1996), with relatively limited amounts of feldspar fractionation affecting some parental magmas. In contrast, we conclude that the RBG and sodic PPB had a common petrogenesis and direct derivation from mantle sources via extensive fractional crystallization of mafic magmas, perhaps accompanied by some crustal assimilation.

Anderson (1983) identified the Llano granites, Red Bluff granitic suite and the PPB as part of an 'anorogenic' magmatic event that occurred $~ 1.1$ Ga ago. The subsurface distribution of these granitic types is not known, and evidence exists that RBG-type granites may be present south of the Grenville Front in west Texas (Barnes, unpublished data). However, 
the $\sim 1.1$ Ga granites in Texas are clearly not part of a single Grenville-age magmatic event because of their distinct petrogenetic histories and tectonic settings.

\section{Acknowledgment}

DRS acknowledges faculty development funds provided by Trinity University. Research on the RBG was supported by a Petroleum Research Fund Grant from the American Chemical Society to CGB. Neutron activation analyses of ERB and some RBG samples were made available through several U.S. Department of Energy University Reactor Sharing Grants provided to DRS and CGB, and administered by the Oregon State University Radiation Center. Data for the sodic PPB were made available by student and faculty participants (G. Kay, B. Saltoun, R. Beane, J. Douglass, Dr J. Noblett and Dr R. Wobus) on the Pikes Peak batholith project, funded by the W.M. Keck Foundation. Dr K. Cameron is thanked for providing $\mathrm{Nd}$ isotope data of RBG late-stage mafic dikes. DRS thanks Dr David Wark at Rensselaer Polytechnic Institute for access to microprobe facilities and stimulating discussions regarding granite and magmatic enclave genesis in the Llano uplift. DRS also thanks the Department of Geological Sciences at the University of Texas-Austin and the Department of Geology and Geophysics at Rice University for access to microprobe facilities. CGB thanks Dr E.Y. Anthony for useful discussions on the petrogenesis of the RBG.

\section{References}

Adams, D.C., Miller, K.C., 1995. Evidence for late Middle Proterozoic extension in the Precambrian basement beneath the Permian basin. Tectonics 14, 1263-1272.

Anderson, J.L., 1983. Proterozoic anorogenic granite plutonism of North America. In: Medaris, L.G. Jr, Byers, C.W., Mickelson, D.M., Shanks, W.C. (Eds.), Proterozoic Geology: Selected Papers from an International Proterozoic Symposium. Geological Society of America Memoir, 161, 133-154.

Anderson, J.L., Bender, E.E., 1989. Nature and origin of Proterozoic A-type granitic magmatism in the southwestern United States of America. Lithos 23, 9-52.

Anderson, J.L., Smith, D.R., 1995. The effects of temperature and $\mathrm{fO}_{2}$ on the Al-inhornblende barometer. American Mineralogist 80, 549-559.

Anthony, E.Y., Barnes, C.G., Chen, W., Hoffer, J.M., Keller, G.R., Marsaglia, K.M., McLemore, V.T., Selley, J.M., Seward, M.A., Shannon, W.M., Thomann, W.F., 1991. Examples of modern rift volcanism and Proterozoic anorogenic magmatism: the Potrillo Volcanic Field of southern New Mexico and the Franklin Mountains of west Texas. New Mexico Bureau of Mines and Mineral Resources Bulletin 137, 1-3.

Barker, D.S., Muehlberger, W.R., Reed, R.M., 1995. Coarse-grained granite at Wirtz Dam. In: Mosher, S. (Ed.), Guide to the Precambrian Geology of the Eastern Llano Uplift. 12th 
International Conference on Basement Tectonics. University of Texas, Austin, Texas, pp. 21-27.

Barker, F., Wanes, D.R., Sharp, W.N., Desborough, G.A., 1975. The Pikes Peak batholith, Colorado Front Range, and a model for the origin of the gabbro-anorthosite-syenitepotassic granite suite. Precambrian Research 2, 97-160.

Barker, F., Hedge, C.E., Millard, H.T., Jr, O'Neil, J.R., 1976. Pikes Peak batholith: geochemistry of some minor elements and isotopes, and implications for magma genesis. In: Epis, R.C., Weimer, R.J. (Eds.), Studies in Colorado Geology, Vol. 8. Colorado School of Mines Professional Contributions, pp. 44-56.

Beane, R.J., 1993. Field relations, petrology and geochemistry of the Sugarloaf complex, Pikes Peak batholith, Colorado. B.A. Honors Thesis, Williams College, Williamstown, MA, U.S.A. (unpublished).

Bebout, G.R., Carlson, W.D., 1986. Fluid evolution and transport during metamorphism: evidence from the Llano uplift, Texas. Contributions to Mineralogy and Petrology 92, 518-529.

Bence, A.E., Albee, A.L., 1968. Empirical correction factors for the electron microanalysis of silicates and oxides. Journal of Geology 76, 382-402.

Bickford, M.E., 1988. The formation of continental crust: Part 1. A review of some principles; Part 2. An application to the Proterozoic evolution of southern North America. Geological Society of America Bulletin 100, 1375-1391.

Bickford, M.E., McLelland, J., Soegaard, K., Nielsen, K.C., 1995. Oblique convergent tectonism in the Grenville of west Texas: a model. Geological Society of America Abstracts with Program 27, A162

Blundy, J.D., Holland, T.J.B., 1990. Calcic amphibole equilibria and a new amphiboleplagioclase geothermometer. Contributions to Mineralogy and Petrology 140, 208224.

Bryant, B., McGrew, L.W., Wobus, R.A., 1981. Geologic map of the Denver $1^{\circ}$ by $2^{\circ}$ Quadrangle, north-central Colorado. U.S. Geological Survey Map I-1163.

Carroll, M.R., Wyllie, P.J., 1990. The system tonalite- $\mathrm{H}_{2} \mathrm{O}$ at $15 \mathrm{kbar}$ and the genesis of calcalkaline magmas. American Mineralogist 75, 345-357.

Copeland, P., Bowring, S.A., 1988. U-Pb zircon and ${ }^{40} \mathrm{Ar} /{ }^{39} \mathrm{Ar}$ ages from Proterozoic rocks, west Texas. Geological Society of America Abstracts with Program 20, 95-96. 
Cosca, M.A., Essene, E.J., Bowman, J.R., 1991. Complete chemical analyses of metamorphic hornblendes: implications for normalizations, calculated $\mathrm{H}_{2} \mathrm{O}$ activities, and thermobarometry. Contributions to Mineralogy and Petrology 108, 472-484.

DePaolo, D.J., 1981. Neodymium isotopes in the Colorado Front Range and crust-mantle evolution in the Proterozoic. Nature 291, 193-196.

Denison, R.E., Lidiak, E.G. Bickford, M.E., Kisvarsanyi, E.B., 1984. Geology and geochronology of Precambrian rocks in the Central Interior Region of the United States. U.S. Geological Survey Professional Paper, 1241C.

Douglass, J., Smith, D.R., 1993. Neodymium isotopic constraints on the origin of alkaline plutons of the Pikes Peak batholith. Geological Society of America Abstracts with Program 25, A261-A262.

Ebadi, A., Johannes, W., 1991. Beginning of melting and composition of first melts in the system Qz-Ab-Or- $\mathrm{H}_{2} \mathrm{O}-\mathrm{CO}_{2}$. Contributions to Mineralogy and Petrology 106, 286-295.

Garrison, J.R., Long, L.E., Richmann, D.L., 1979. Rb-Sr and K-Ar geochronologic and isotopic studies, Llano uplift, central Texas. Contributions to Mineralogy and Petrology 69, 361-374.

Giambalvo, E., 1993. Amphibole chemistry in alkaline igneous rocks of the Pikes Peak batholith, Colorado. B.A. Honors Thesis, Amherst College, Amherst, MA, U.S.A. (unpublished).

Giret, A., Bonin, B., Leger, J.M., 1980. Amphibole compositional trends in oversaturated and undersaturated alkaline plutonic ring-complexes. Canadian Mineralogist 18,481-495.

Hammond, J.G., 1986. Geochemistry and petrogenesis of Proterozoic diabase in the southern Death Valley region of California. Contributions to Mineralogy and Petrology 93, 312-321.

Harrison, T.M., Watson, E.B., 1984. The behavior of apatite during crustal anatexis: equilibrium and kinetic considerations. Geochimica et Cosmochimica Acta 48, 14641477.

Howard, K., 1991. Intrusion of horizontal dikes: Tectonic significance of Middle Proterozoic diabase sheets widespread in the upper crust of the southwestern United States. Journal of Geophysical Research 96, 12461-12478.

Hutchinson, R.M., 1956. Structure and petrology of the Enchanted Rock batholith, Llano and Gillespie Counties, Texas. Geological Society of America Bulletin 67, 763-806.

Johnson, L.A., Rogers, J.J.W., Nagy, R.M., 1976. Composition of the Precambrian Llano uplift, central Texas. Geochimica et Cosmochimica Acta 40, 1419-1420. 
Kargi, H., Barnes, C.G., 1995. A Grenville-age layered intrusion in the subsurface of west Texas: petrology, petrography and possible tectonic setting. Canadian Journal of Earth Sciences 32, 2159-2166.

Kay, G., 1993. The petrology and geochemistry of the Mount Rosa granite, Pikes Peak batholith. B.A. Thesis, Colorado College, Colorado Springs, CO, U.S.A. (unpublished).

Keller, G.R., Hills, J.M., Baker, M.R., Wallin, E.T., 1989. The Nellie intrusion: a basic stratiform intrusion in the Central basin platform in west Texas. Geology 17, 1049-1052.

Keppel, D., 1940. Concentric patterns in the granites of the Llano-Burnet region, Texas. Geological Society of America Bulletin 51, 971-1000.

Mosher, S., 1993. Exposed Proterozoic rocks of Texas (part of "Proterozoic rocks east and southeast of the Grenville front"). In: Reed, J.C. Jr, Bickford, M.E., Houston, R.S., Link, P.K., Rankin, D.W., Sims, P.K., Van Schmus, W.R. (Eds.), Precambrian: Conterminous U.S. Boulder, Colorado, The Geology of North America, Vol. C-2. Geological Society of America, pp. 366-378.

Mosher, S., 1996. Guide to the Precambrian geology of the eastern Llano uplift. Geological Society of America, South-Central Section, Field Trip Guidebook.

Nelson, B.K., DePaolo, D.J., 1985. Rapid production of continental crust 1.7 to 1.9 b.y. ago: $\mathrm{Nd}$ isotopic evidence from the basement of the North American mid-continent. Geological Society of America Bulletin 96, 746-754.

Norman, D.I., Condie, K.C., Smith, R.W., Thomann, W.F., 1987. Geochemical and Sr and Nd isotopic constraints on the origin of late Proterozoic volcanics and associated tin-bearing granites from the Franklin Mountains, west Texas. Canadian Journal of Earth Sciences 24, 830-839.

Paces, J.B., Bell, K., 1989. Non-depleted sub-continental mantle beneath the Superior Province of the Canadian Shield: Nd-Sr isotopic and trace element evidence from Midcontinent Rift basalts. Geochimica et Cosmochimica Acta 53, 2023-2035.

Patchett, P.J., Ruiz, J., 1989. Nd isotopes and the origin of Grenville-age rocks in Texas: implications for Proterozoic evolution of the United States mid-continent region. Journal of Geology 97, 685-695.

Pearce, J.A., Harris, N.B.W., Tindle, A.G., 1984. Trace element discrimination diagrams for the tectonic interpretation of granitic rocks. Journal of Petrology 25, 956-983.

Pittenger, M.A., Marsaglia, K.M., Bickford, M.E., 1994. Depositional history of the Middle Proterozoic Castner Marble and basalt Mundy Breccia, Franklin Mountains, west Texas. Journal of Sedimentary Research B64, 282-297. 
Pouchou, J.L., Pichoir, F., 1987, PAP $(\phi-\rho-z)$ procedure for improved quantitative analysis. In: Armstrong, J.T (Ed.), Microbeam Analysis. San Francisco Press, San Francisco. CA, U.S.A., pp. 85-87.

Reed, R., 1995. A complex strain and intrusion fabric related to trans-solidus deformation: the Wolf Mountain intrusion, Llano uplift, Texas. U.S. Geological Survey Circular 1129, 124-125.

Roback, R.C., 1996. Meso-proterozoic polymetamorphism and magmatism in the Llano uplift, central Texas: Geological Society of America, abstracts with programme 38, A377.

Roback, R.C., James, E.W., Whitefield, C., Connelly, J., 1995. Tectonic assembly of "Grenville" terranes in the Llano uplift, central Texas: evidence from $\mathrm{Pb}$ and $\mathrm{Sm}-\mathrm{Nd}$ isotopes. Geological Society of America Abstracts with Programs 27, A398

Roberts, M.P., Clemens, J.D., 1993. Origin of high-potassium, calc-alkaline, I-type granitoids. Geology 21, 825-828.

Roths. P., 1993. Geochemical and geochronological studies of the Grenville-age (1250-1000 Ma) Allamore and Hazel Formations, Hudspeth and Culberson Counties, west Texas. Geological Society of America, South-Central Section, Field Trip Guidebook, pp. 11-35.

Rudnick, R.L., Presper, T., 1990. Geochemistry of intermediate- to high-pressure granulites. In: Vielzeuf, D., Vidal, Ph. (Eds.), Granulites and Crustal Evolution. Kluwer Academic Publishers, Netherlands, pp. 523-550.

Saltoun, B.W., 1993. A petrologic and geochemical analysis of the fayalite-bearing granitoids, Mount Rosa intrusive center, Colorado. Senior Independent Study, The College of Wooster, Wooster, OH, U.S.A. (unpublished).

Scott, G.R., Taylor, R.B., Epis, R.C., Wobus, R.A., 1978. Geologic map of the Pueblo $1^{\circ}$ by $2^{\circ}$ Quadrangle, south-central Colorado. U.S. Geological Survey Map I-1022.

Shannon, W.M., 1994. Petrogenesis of Middle Proterozoic alkaline granitic rocks, Franklin Mountains, west Texas. Ph.D. Thesis, Texas Tech University, Lubbock. TX, U.S.A. (unpublished).

Shannon, W.M., Barnes, C.G., Bickford, M.E., 1997. Grenville magmatism in west Texas: petrology and geochemistry of the Red Bluff granitic suite. Journal of Petrology, 38.

Skjerlie, K.J., Johnston, A.D., 1993. Fluid absent melting behavior of an F-rich tonalitic gneiss at mid-crustal pressures: implications for the generation of anorogenic granites. Journal of Petrology 34, 785-815. 
Smith, D.R., Wark, D.A., 1992. Magmatic enclaves in the Enchanted Rock batholith, Llano uplift, Texas. Geological Society of America Abstracts with Programs 24, 47.

Stacey, J.S., Kramers, J.D., 1975. Approximation of terrestrial lead isotope evolution by a two-stage model. Earth and Planetary Science Letters 26, 207-221.

Sturm, M., Smith, D., Beane, R., Wobus, R.A., Gustavson, B., Kay, G., Saltoun, B., Stewart, J., 1993. Geochemistry of late stage alkaline intrusions of the Pikes Peak batholith, Colorado. Geological Society of America Abstracts with Programs 25, 261.

Thomas, J.J., Shuster, R.D., Bickford, M.E., 1984. A terrane of 1,350 to 1,400 m.y.-old silicic volcanic and plutonic rocks in the buried Proterozoic of the mid-continent and in the Wet Mountains, Colorado. Geological Society of America Bulletin 95, 1150-1157.

Van Schmus, W.R., Hinze, W.J., 1993. Midcontinent rift system (part of "Transcontinental Proterozoic provinces"). In: Reed, J.C. Jr., Bickford, M.E., Houston, R.S., Link, P.K., Rankin, D.W., Sims, P.K., Van Schmus, W.R. (Eds.), Precambrian: Conterminous U.S. Boulder, Colorado, Geological Society of America, Vol. C-2. The Geology of North America, pp. 292-303.

Walker, N., 1992. Middle Proterozoic geologic evolution of Llano uplift, Texas: evidence from U-Pb zircon geochronology. Geological Society of America Bulletin 104, 494-504.

Wasserburg, G.J., Wetherill, G.W., Silver, L.T., Flawn, P.T., 1962. A study of the ages of the Precambrian of Texas. Journal of Geophysical Research 67,4021-4047.

Watson, E.B.. Harrison, T.M., 1983. Zircon saturation revisited: temperature and composition effects in a variety of crustal magma types. Earth and Planetary Science Letters 64, 295-304.

Whalen, J.B., Currie, K.L., Chappell, B.W., 1987. A-type granites: geochemical characteristics, discriminations and petro- genesis. Contributions to Mineralogy and Petrology 95, 407-419.

Whalen, J.B., Jenner, G.A., Longstaffe, F.J., Robert, F., Gariepy, C., 1996. Geochemical and isotopic $(\mathrm{O}, \mathrm{Nd}, \mathrm{Pb}$ and $\mathrm{Sr}$ ) constraints on A-type granite petrogenesis based on the Topsails igneous suite, Newfoundland Appalachians. Journal of Petrology 37. 14631489.

Wobus, R.A., 1976. New data on potassic and sodic plutons of the Pikes Peak batholith, central Colorado. In: Epis, R.C., Weimer, R.J. (Eds.), Studies in Colorado Geology, Vol. 8. Colorado School of Mines Professional Contributions, pp. 57-67.

Wobus, R.A., Anderson, R.S., 1978. Petrology of the Precambrian intrusive center at Lake George, southern Front Range, Colorado. U.S. Geological Survey Journal of Research 6, 82-94. 
Wobus, R.A., Hutchinson, R.M., 1988. Proterozoic plutons and pegmatites of the Pikes Peak region, Colorado. In: Holden, G.S. (Ed.), Geological Society of America Field Trip Guidebook, Vol. 12. Colorado School of Mines Professional Contributions, pp. 35-42.

Wooden, J.L, Stacey. J.S., Howard, K.A., 1988. Pb isotopic evidence for the formation of Proterozoic crust in the south- western United States. In: Ernst, W.G. (Ed.), Metamorphism and Crustal Evolution of the Western United States, Rubey Volume VII. Prentice-Hall, Englewood Cliffs, New Jersey, pp. 69-86.

Zartman, R.E., Doe, B.R., 1981. Plumbotectonics: the model. Tectonophysics 75. 135-162.

Figure 1:

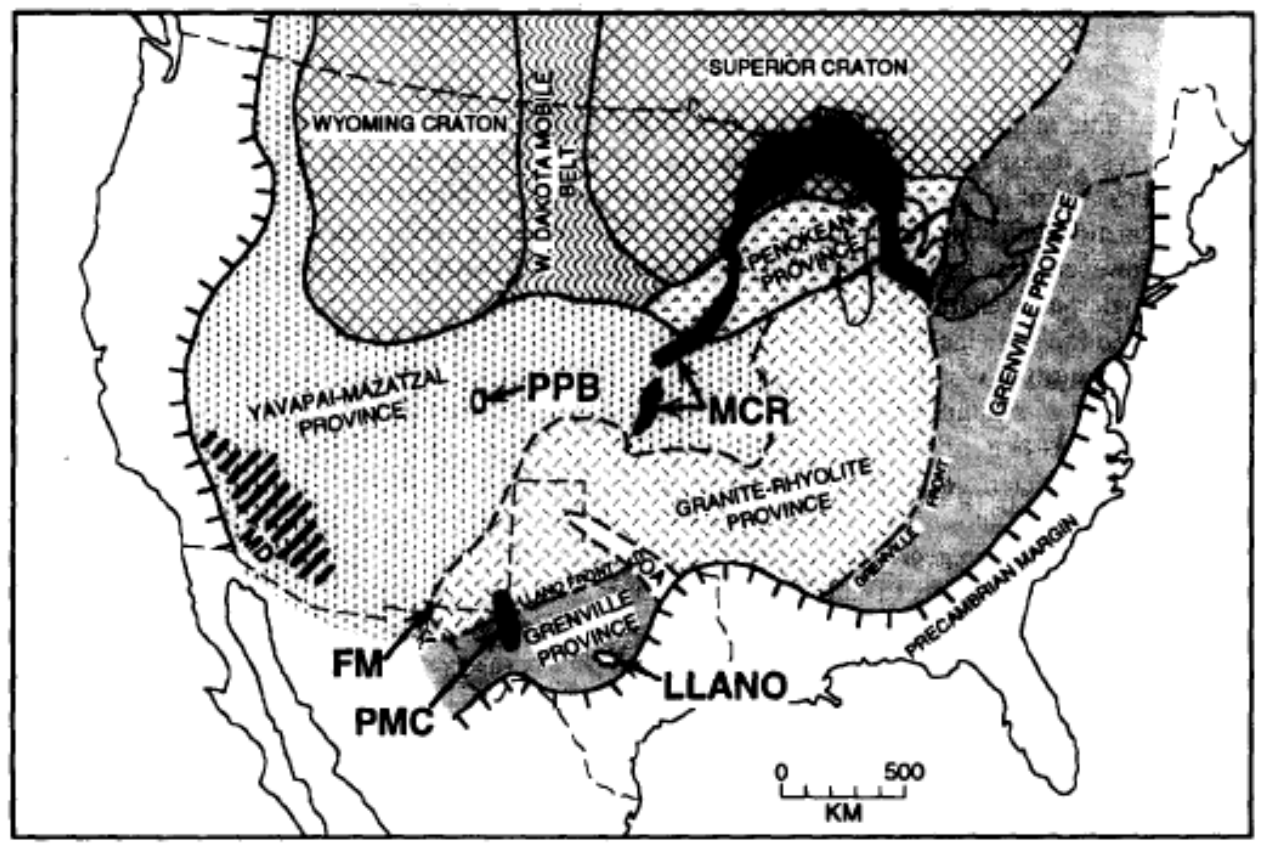

Fig. 1. Simplified map of Precambrian provinces in central North America showing the Archean Wyoming and Superior cratons, 1.8-2.5 Ga Penokean province and West Dakota mobile belt, and the younger Yavapai-Mazatzal (1.55-1.70 Ga), Granite-Rhyolite (1.34-1.50 Ga), and Grenville (1.1-1.35 Ga) provinces to the south [after Bickford (1988)]. Circa $1.1 \mathrm{Ga}$ granitic systems discussed here are the RBG Suite in the Franklin Mountains (FM) of west Texas, the ERB in the Llano uplift of central Texas, and the (PPB) in central Colorado. Contemporaneous mafic magmatism occurred in the Mid-Continent Rift (MCR), the rift-related Pecos mafic intrusive complex (PMC), and as dikes and sills in the Mojave Desert region (MD). SOA is the Cambrian southern Oklahoma aulacogen. 
Table 1:

Table 1

Summary of isotopic data

\begin{tabular}{llrl}
\hline & Initial ${ }^{87} \mathrm{Sr} /{ }^{86} \mathrm{Sr}$ & $\epsilon_{\text {Nadr) }}$ & $\delta^{18} \mathrm{O}(\%)$ \\
\hline RBG suite & $\sim 0.7034^{\mathrm{a}}$ & +2.5 to $+3.8^{\mathrm{a}, \mathrm{b}}$ & +6.8 to $+9.6^{\mathrm{e}}$ \\
PPB: & & & \\
Sodic & $0.7052-0.7068^{\mathrm{d}}$ & -0.8 to $+2.0^{\mathrm{e}}$ & +7.7 to $+8.9^{\mathrm{d}}$ \\
Potassic & $0.7067-0.7117^{\mathrm{d}}$ & -0.8 to $-2.3^{\mathrm{e}}$ & +8.2 to $+9.5^{\mathrm{d}}$ \\
Llano granites: & $\sim 0.7060^{\mathrm{r}}$ & +2.6 to $+4.3^{\mathrm{b} .8}$ & +9.3 to $9.7^{\mathrm{h}}$ \\
ERB & $\sim 0.7050^{f}$ & +2.7 to $+4.3^{8}$ & \\
\hline
\end{tabular}

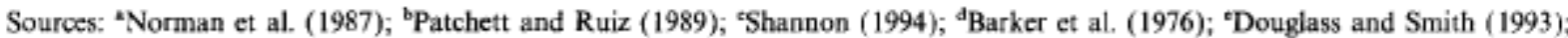
'Garrison et al. (1979); "this study; "'Bebout and Carlson (1986).

Figure 2:

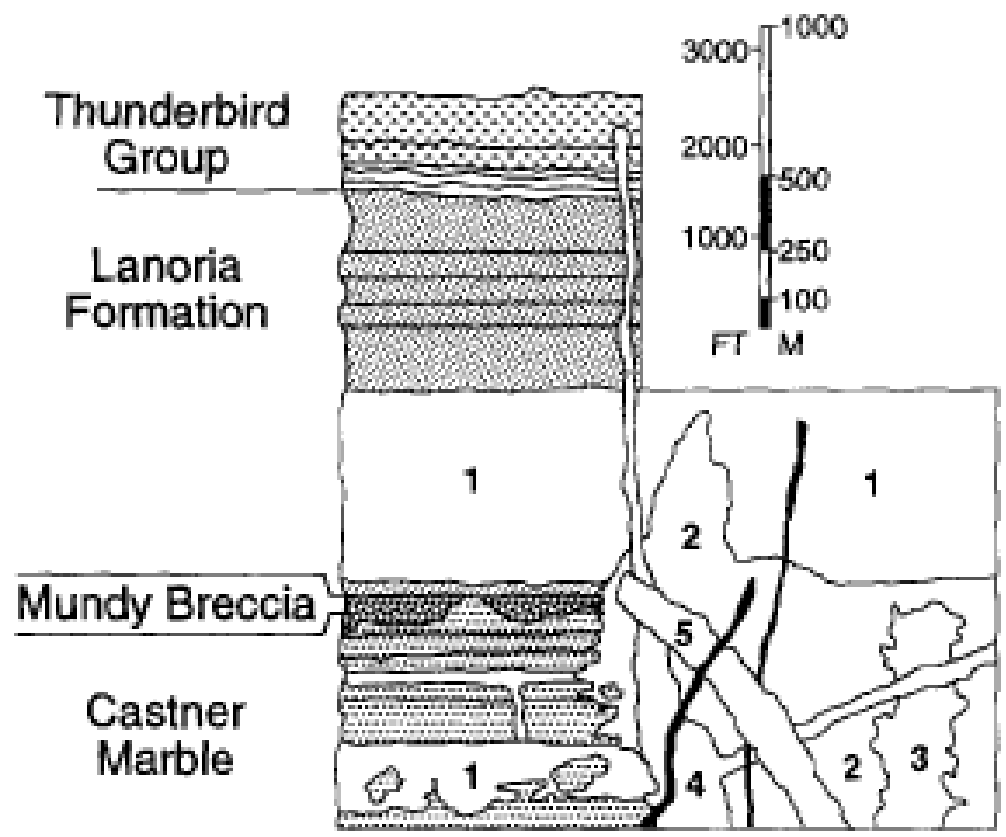

Fig. 2. Diagrammatic stratigraphic section of Precambrian rocks in the Franklin Mountains [after Anthony et al. (1991)]. Stages of the RBG Suite are numbered; the Thunderbird Group represents coeval trachytic and rhyolitic deposits. Host rocks are $1.25 \mathrm{Ga}$ [U-Pb age; Pittenger et al. (1994)] calcareous metasedimentary rocks (Castner Marble), basaltic breccia (Mundy Breccia), and siliciclastic sandstone and shale (Lanoria Formation). 
Figure 3:
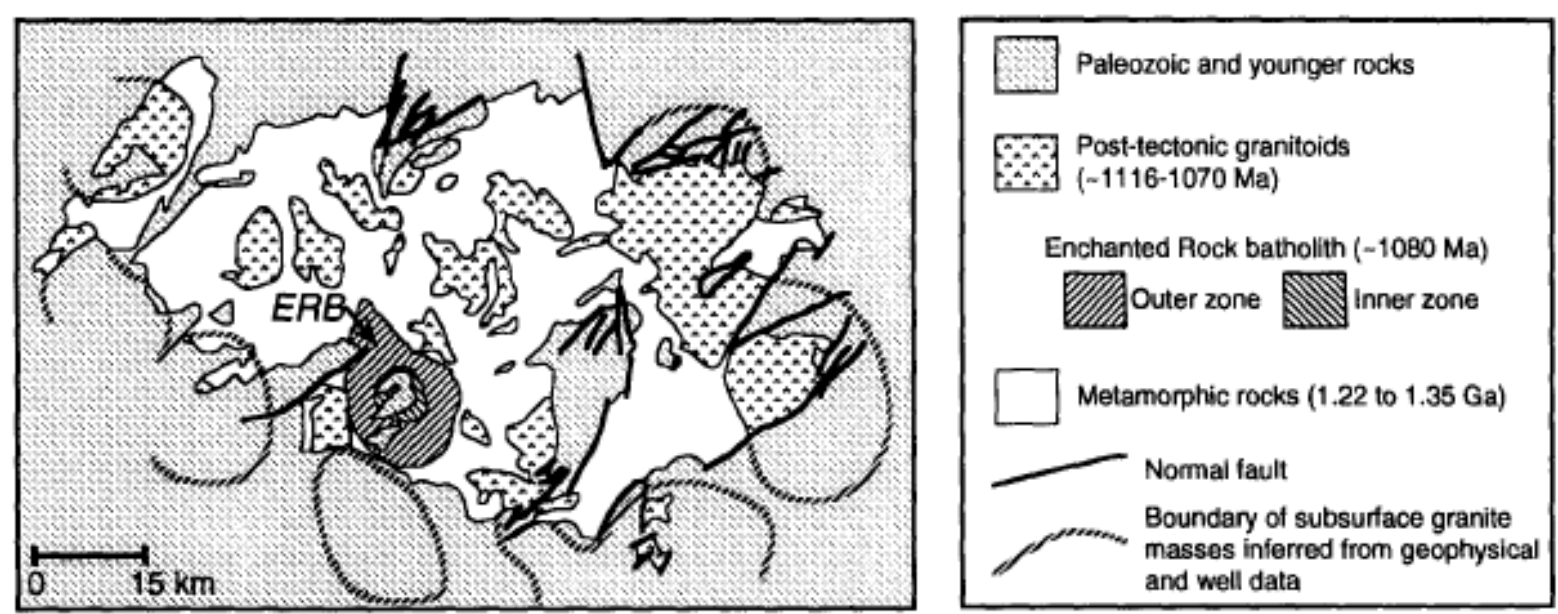

Fig. 3. Simplified geologic map of the Llano uplift showing major rock units [after Mosher (1993) and Walker (1992)]. 'Metamorphic rocks' are polymetamorphosed and deformed schists and gneisses with U-Pb zircon ages of 1.2-1.35 Ga. Younger 'post-tectonic' granitoid plutons include the $1.08 \mathrm{Ga}$ (Walker, 1992) ERB. The batholith is compositionally and texturally zoned and is divided into an outer and inner zone (sec text for discussion).

Figure 4:

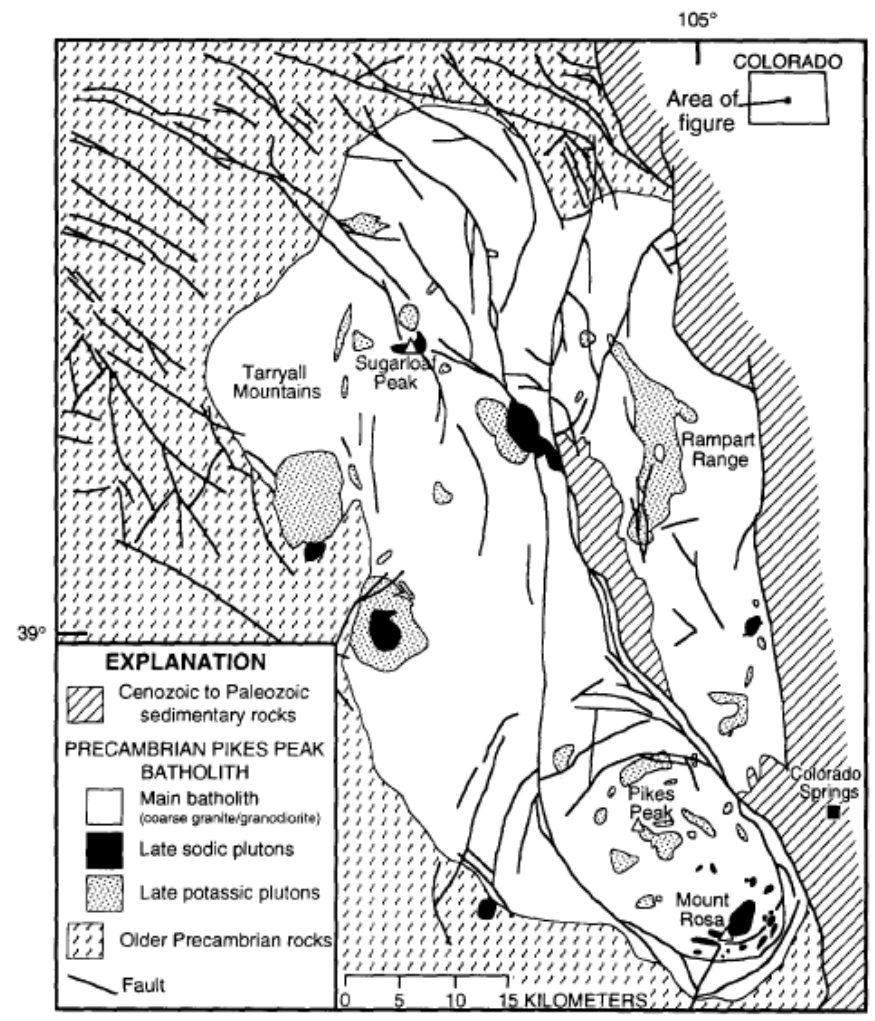

Fig. 4. Geologic map of the PPB [after Bryant et al. (1981) and Scott et al. (1978)]. 
Table 2:

Table 2

Representative analyses ${ }^{2}$ of biotites from the ERB

\begin{tabular}{|c|c|c|c|c|c|c|}
\hline $\begin{array}{l}\text { Sample } \\
\text { Rock type }\end{array}$ & $\begin{array}{l}\text { ER-23Z } \\
\text { Granite of ERB } \\
\text { outer zone }\end{array}$ & $\begin{array}{l}\text { ERB-23Z } \\
\text { Granite of ERB } \\
\text { outer zone }\end{array}$ & $\begin{array}{l}\text { ERB-8A } \\
\text { Granite of ERB } \\
\text { inner zone }\end{array}$ & $\begin{array}{l}\text { ERB-20 } \\
\text { Granite of ERB outer } \\
\text { zone, adjacent to enclave }\end{array}$ & $\begin{array}{l}\text { ERB-20 } \\
\text { Margin of enclave } \\
\text { adjacent to host granite }\end{array}$ & $\begin{array}{l}\text { ERB-20 } \\
\text { Enclave } \\
\text { interior }\end{array}$ \\
\hline $\mathrm{SiO}_{2}$ & 35.15 & 33.79 & 36.27 & 35.34 & 36.11 & 36.33 \\
\hline $\mathrm{TiO}_{2}$ & 2.46 & 3.67 & 2.60 & 1.82 & 1.97 & 1.39 \\
\hline $\mathrm{Al}_{2} \mathrm{O}_{3}$ & 13.46 & 13.97 & 15.01 & 14.01 & 14.06 & 13.78 \\
\hline $\mathrm{FeO}$ & 30.06 & 29.80 & 24.34 & 27.43 & 28.11 & 25.19 \\
\hline $\mathrm{MnO}$ & 0.55 & 0.49 & 0.69 & 0.51 & 0.48 & 0.45 \\
\hline $\mathrm{MgO}$ & 5.59 & 4.76 & 7.05 & 6.32 & 6.35 & 8.33 \\
\hline $\mathrm{CaO}$ & 0.00 & 0.05 & 0.02 & 0.00 & 0.00 & 0.01 \\
\hline $\mathrm{Na}_{2} \mathrm{O}$ & 0.09 & 0.07 & 0.07 & 0.07 & 0.07 & 0.08 \\
\hline $\mathrm{K}_{2} \mathrm{O}$ & 9.09 & 8.58 & 9.59 & 9.45 & 9.65 & 9.73 \\
\hline $\mathrm{F}$ & N.A. ${ }^{b}$ & 0.94 & N.A. & N.A. & N.A. & N.A. \\
\hline $\mathrm{Cl}$ & N.A. & 0.10 & N.A. & N.A. & N.A. & N.A. \\
\hline Sum & 96.45 & 95.18 & 95.64 & 94.95 & 96.79 & 95.30 \\
\hline \multicolumn{7}{|c|}{ Atomic proportions on the basis of 22 oxygens } \\
\hline $\mathrm{Si}$ & 5.619 & 5.473 & 5.673 & 5.671 & 5.690 & 5.739 \\
\hline $\mathrm{Ti}$ & 0.296 & 0.447 & 0.306 & 0.220 & 0.233 & 0.165 \\
\hline A] & 2.537 & 2.668 & 2.768 & 2.652 & 2.611 & 2.567 \\
\hline $\mathrm{Fe}$ & 4.019 & 4.037 & 3.184 & 3.682 & 3.703 & 3.328 \\
\hline Mn & 0.074 & 0.067 & 0.091 & 0.070 & 0.064 & 0.060 \\
\hline $\mathrm{Mg}$ & 1.332 & 1.149 & 1.643 & 1.511 & 1.490 & 1.960 \\
\hline $\mathrm{Ca}$ & 0.000 & 0.009 & 0.003 & 0.000 & 0.000 & 0.002 \\
\hline $\mathrm{Na}$ & 0.028 & 0.022 & 0.021 & 0.021 & 0.021 & 0.026 \\
\hline K & 1.854 & 1.773 & 1.914 & 1.935 & 1.940 & 1.960 \\
\hline Sum & 15.758 & 15.644 & 15.604 & 15.761 & 15,752 & 15.806 \\
\hline $\mathrm{Fe} /(\mathrm{Fe}+\mathrm{Mg})$ & 0.75 & 0.78 & 0.66 & 0.71 & 0.71 & 0.63 \\
\hline
\end{tabular}

*Biotites were analyzed on automated four-spectrometer JEOL 733 microprobes at the University of Texas-Austin (samples ERB-23Z. and ERB-8A) and Rensselaer Polytechnic Institute (sample ERB-20). Accelerating voltage was $15 \mathrm{kV}$, beam current was $20 \mathrm{nA}$, and beam diameter was 5 or $10 \mu \mathrm{m}$; a Bence and Albee (1968) data reduction procedure was used.

${ }^{b}$ N.A., not analyzed. 
Table 3:

Table 3

Representative analyses ${ }^{2}$ of amphiboles from the ERB

\begin{tabular}{|c|c|c|c|c|c|}
\hline Sample & ERB-2 & ERB-23 & ERB-23 & ERB-5 & ERB-7az \\
\hline Rock type & $\begin{array}{l}\text { Granite of ERB } \\
\text { outer zone }\end{array}$ & $\begin{array}{l}\text { Granite of ERB } \\
\text { outer zone }\end{array}$ & $\begin{array}{l}\text { Granite of ERB } \\
\text { outer zone }\end{array}$ & Enclave & Enclave \\
\hline $\mathrm{SiO}_{2}$ & 38.52 & 40.32 & 43.70 & 42.30 & 42.23 \\
\hline $\mathrm{TiO}_{2}$ & 1.09 & 1.12 & 0.89 & 1.65 & 0.65 \\
\hline $\mathrm{Al}_{2} \mathrm{O}_{3}$ & 9.56 & 9.52 & 8.84 & 9.22 & 8.99 \\
\hline $\mathrm{FeO}^{\mathrm{n}}$ & 28.71 & 28.18 & 26.15 & 24.47 & 23.91 \\
\hline $\mathrm{MgO}$ & 3.15 & 4.05 & 4.77 & 5.47 & 6.49 \\
\hline $\mathrm{MnO}$ & 0.64 & 0.80 & 0.52 & 0.78 & 0.80 \\
\hline $\mathrm{CaO}$ & 11.52 & 10.87 & 11.09 & 11.24 & 11.41 \\
\hline $\mathrm{Na}_{2} \mathrm{O}$ & 1.63 & 1.89 & 1.29 & 1.17 & 1.49 \\
\hline $\mathrm{K}_{2} \mathrm{O}$ & 1.42 & 1.47 & 1.61 & 1.49 & 1.49 \\
\hline $\mathrm{F}$ & N.A. ${ }^{b}$ & 0.73 & 0.53 & N.A. & N.A. \\
\hline $\mathrm{Cl}$ & N.A. & 0.14 & 0.07 & N.A. & N.A. \\
\hline $\mathrm{Fe}_{2} \mathrm{O}_{3}$, calc & 4.32 & 6.39 & 2.76 & 3.38 & 4.60 \\
\hline $\mathrm{FeO}$, calc & 24.83 & 22.43 & 23.66 & 21.43 & 19.77 \\
\hline Total & 96.67 & 99.69 & 99.12 & 98.13 & 97.92 \\
\hline \multicolumn{6}{|c|}{ Formula per 13 cations, setrahedral site } \\
\hline $\mathrm{Si}$ & 6.271 & 6.342 & 6.747 & 6.571 & 6.562 \\
\hline$[4] \mathrm{Al}$ & 1.729 & 1.658 & 1.253 & 1.429 & 1.438 \\
\hline $\mathrm{Al}($ total $)$ & 1.835 & 1.765 & 1.608 & 1.688 & 1.647 \\
\hline \multicolumn{6}{|l|}{ M1,2,3 sites } \\
\hline$[6] \mathrm{Al}$ & 0.105 & 0.107 & 0.355 & 0.259 & 0.209 \\
\hline $\mathrm{Ti}$ & 0.133 & 0.132 & 0.103 & 0.193 & 0.076 \\
\hline $\mathrm{Fe}^{3+}$ & 0.529 & 0.756 & 0.321 & 0.395 & 0.538 \\
\hline $\mathrm{Mg}$ & 0.764 & 0.948 & 1.097 & 1.266 & 1.503 \\
\hline $\mathrm{Mn}$ & 0.088 & 0.106 & 0.067 & 0.103 & 0.105 \\
\hline $\mathrm{Fe}^{2+}$ & 3.380 & 2.951 & 3.056 & 2.784 & 2.569 \\
\hline \multicolumn{6}{|l|}{ M4 site } \\
\hline $\mathrm{Ca}$ & 2.000 & 1.831 & 1.834 & 1.871 & 1.900 \\
\hline $\mathrm{Na}$ & 0.000 & 0.169 & 0.166 & 0.129 & 0.100 \\
\hline \multicolumn{6}{|l|}{ A site } \\
\hline $\mathrm{Ca}$ & 0.009 & 0.000 & 0.000 & 0.000 & 0.000 \\
\hline $\mathrm{Na}$ & 0.514 & 0.407 & 0.220 & 0.223 & 0.349 \\
\hline $\mathrm{K}$ & 0.295 & 0.294 & 0.316 & 0.295 & $0.29 \mathrm{I}$ \\
\hline $\mathrm{Fe} / \mathrm{Fe}+\mathrm{Mg}$ & 0.84 & 0.80 & 0.75 & 0.72 & 0.67 \\
\hline
\end{tabular}

"Amphiboles in sample ERB-23 were analyzed on an automated Cameca SX50 microprobe at Rice University. Accelerating voltage was $15 \mathrm{kV}$, beam current was $20 \mathrm{nA}$, and beam diameter was $5 \mu \mathrm{m}$; data were reduced with the procedure of Pouchou and Pichoir (1987). The other amphibole analyses were obtained on an automated four-spectrometer JEOL 733 microprobe at the University of Texas, The same operating conditions wre employed, but the data were reduced using a Bence and Albee (1968) routine. "N.A., not analyzed. 
Figure 5:

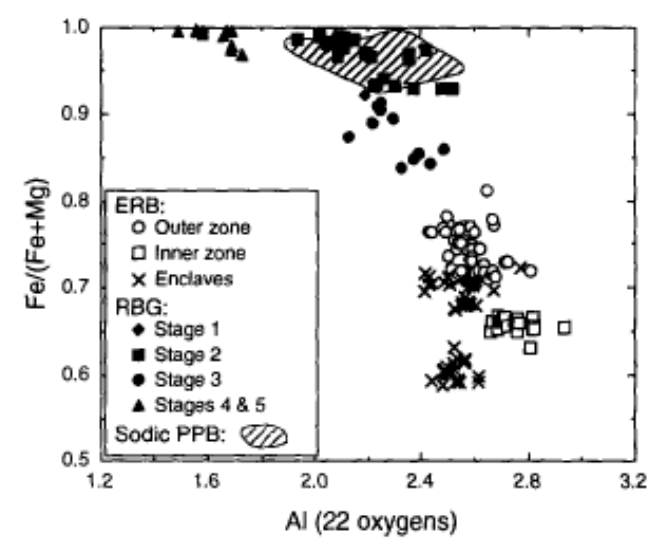

Fig. 5. $\mathrm{Fe} /(\mathrm{Fe}+\mathrm{Mg})$ versus $\mathrm{Al}$ (based on 22 oxygen atoms) in micas from the RBG, ERB and sodic PPB (ruled field). Other symbols are as follows: $\bullet$ RBG stage 1; $\mathbf{\square}$, RBG stage 2; $\bullet$ RBG stage 3; $\Lambda$, RBG stages 4 and 5. O, ERB outer zone; $\square$, ERB inner zone; $\times$, ERB magnatic enclaves.

\section{Figure 6:}
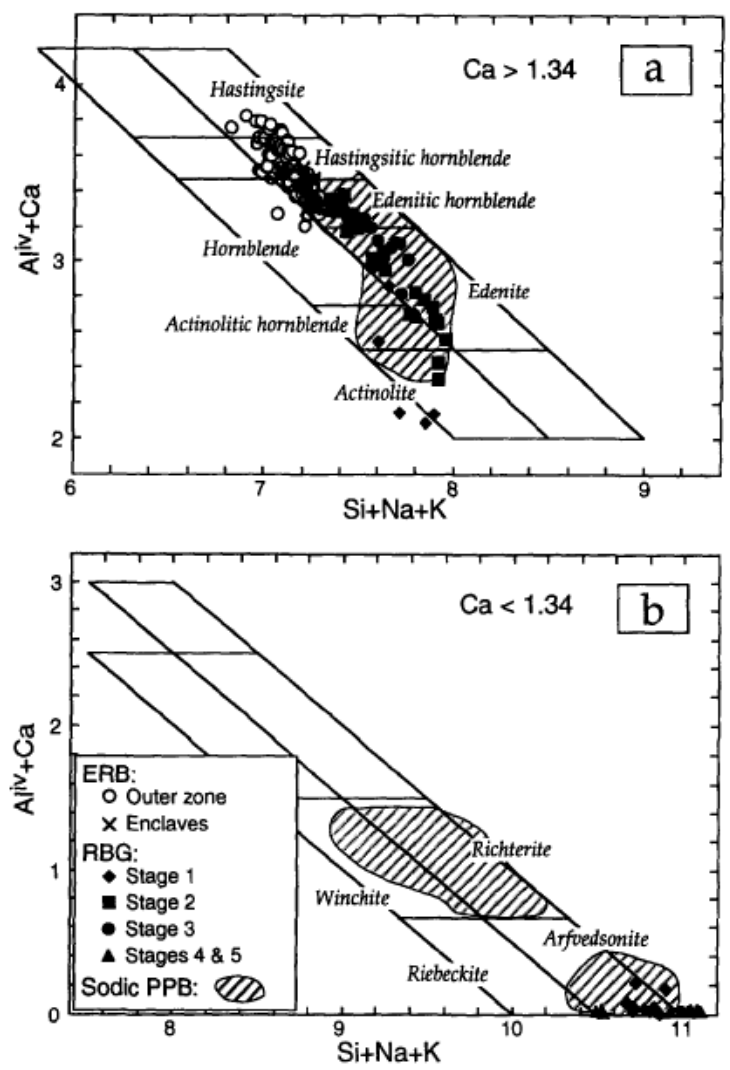

Fig. 6. Amphibole classification [after Giret et al. (1980)] for samples from the RBG, ERB and sodic PPB. Symbols and field as in Fig. 5. Coordinates in atoms per formula unit. (a) Amphiboles with formula $\mathrm{Ca}>1.34$. (b) Amphiboles with formula $\mathrm{Ca}<1.34$; note that none of the ERB samples contain sodic amphiboles. 
Figure 7:

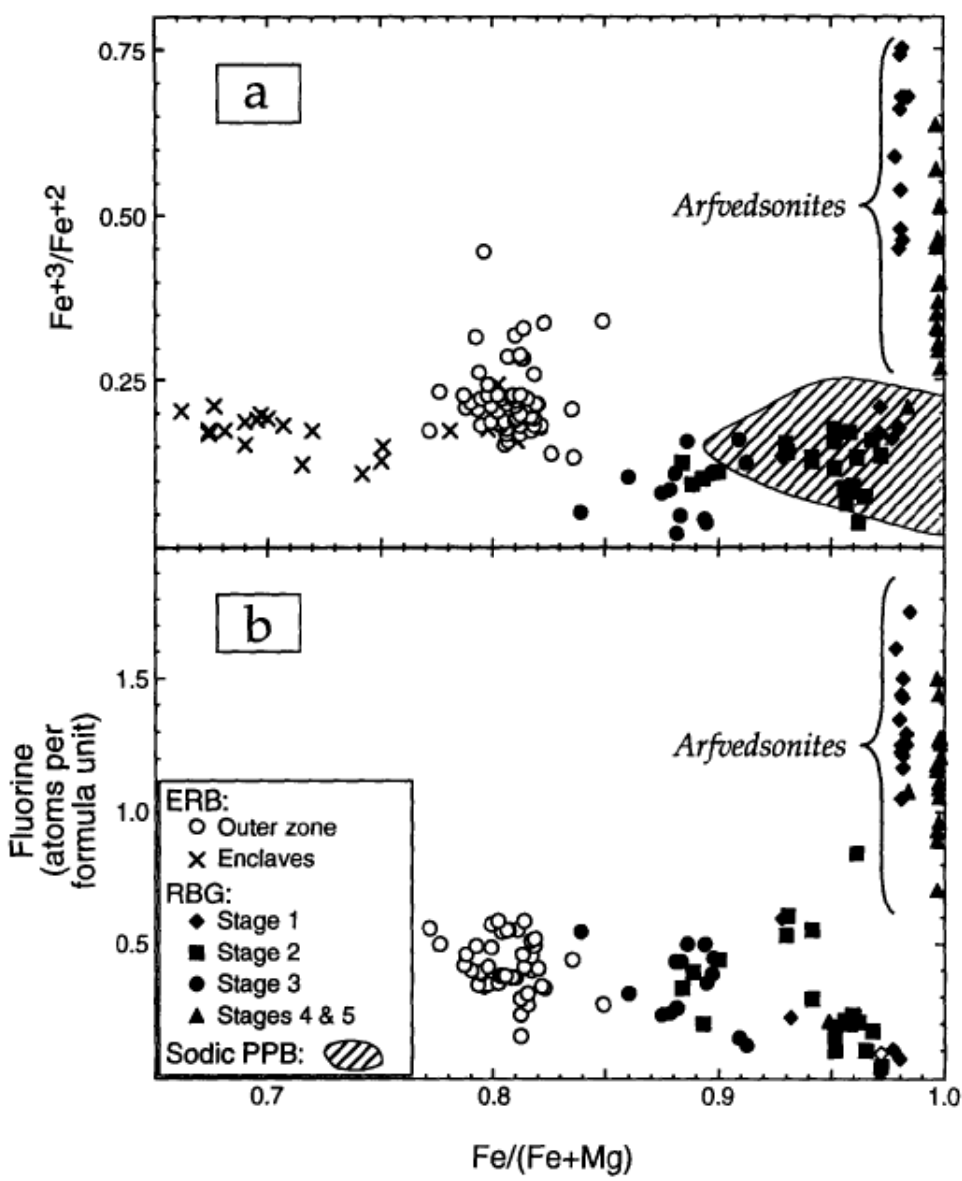

Fig. 7. (a) $\mathrm{Fe}^{+3} / \mathrm{Fe}^{+2}$ and (b) fluorine in amphiboles as a function of $\mathrm{Fe} /(\mathrm{Fe}+\mathrm{Mg})$; symbols and field as in Fig. 5 . 
Figure 8:

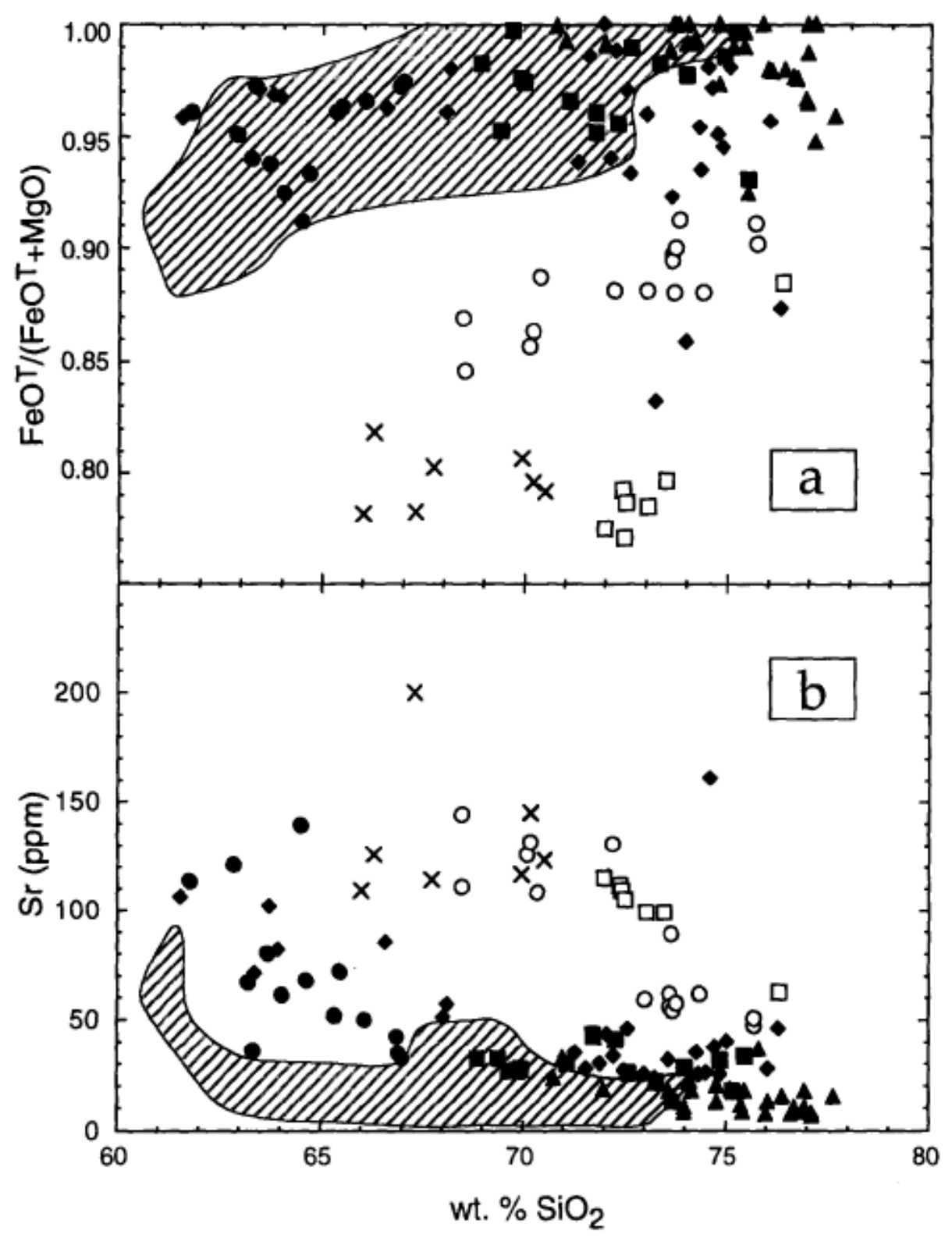

Fig. 8. (a) $\mathrm{FeO}^{\mathrm{T}} /\left(\mathrm{FeO}^{\top}+\mathrm{MgO}\right.$ ) and (b) $\mathrm{Sr}$ (ppm) versus silica (wt $\%$ ) in bulk-rock samples of the RBG, ERB and sodic PPB; symbols and field as in Fig. 5. 
Table 4:

Table 4

Representative chemical analyses ${ }^{a}$ of granitic rocks of the RBG suite

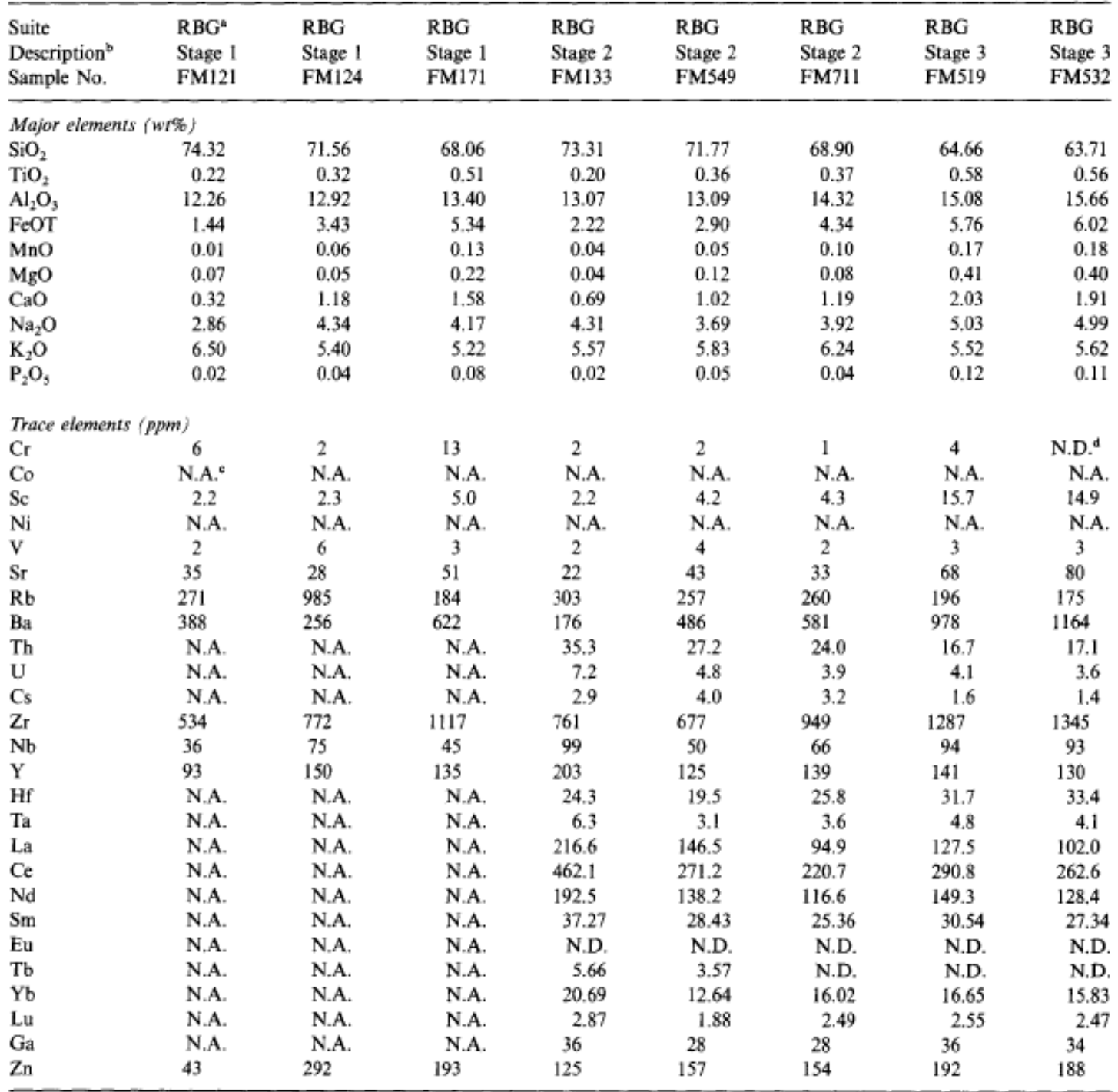

- Shannon et al. (1997) describe techniques used in the analysis of RBG samples. 'See text for further discussion.

'N.A., not analyzed.

${ }^{a}$ N.D., not detected. 
Table 5:

Table 5

Further representative chemical analyses ${ }^{x}$ of granitic rocks of the RBG suite

\begin{tabular}{|c|c|c|c|c|c|c|c|}
\hline $\begin{array}{l}\text { Suite } \\
\text { Description } \\
\text { Sample No. }\end{array}$ & $\begin{array}{l}\text { RBG } \\
\text { Stage } 3 \\
\text { FM538 }\end{array}$ & $\begin{array}{l}\text { RBG } \\
\text { Stage } 4 \\
\text { FM136 }\end{array}$ & $\begin{array}{l}\text { RBG } \\
\text { Stage } 4 \\
\text { FM146 }\end{array}$ & $\begin{array}{l}\text { RBG } \\
\text { Stage } 5 \\
\text { FM551 }\end{array}$ & $\begin{array}{l}\text { RBG } \\
\text { Stage } 5 \\
\text { FM542 }\end{array}$ & $\begin{array}{l}\text { RBG } \\
\text { Stage 5 } \\
\text { FM623 }\end{array}$ & $\begin{array}{l}\text { RBG } \\
\text { Stage } 5 \\
\text { FMNK1 }\end{array}$ \\
\hline \multicolumn{8}{|c|}{ Major elements (wt\%) } \\
\hline $\mathrm{SiO}_{2}$ & 62.89 & 76.62 & 77.65 & 76.92 & 71.01 & 76.95 & 74.14 \\
\hline $\mathrm{TiO}_{2}$ & 0.54 & 0.12 & 0.07 & 0.02 & 0.21 & 0.10 & 0.14 \\
\hline $\mathrm{Al}_{2} \mathrm{O}_{3}$ & 16.19 & 11.84 & 11.93 & 12.98 & 8.94 & 11.46 & 9.34 \\
\hline FeOT & 5.99 & 1.63 & 0.94 & 0.57 & 9.05 & 2.36 & 5.57 \\
\hline $\mathrm{MnO}$ & 0.19 & 0.00 & 0.01 & 0.01 & 0.13 & 0.03 & 0.09 \\
\hline $\mathrm{MgO}$ & 0.31 & 0.04 & 0.04 & 0.02 & 0.07 & 0.03 & 0.05 \\
\hline $\mathrm{CaO}$ & 2.28 & 0.46 & 0.53 & 0.16 & 0.58 & 0.17 & 0.60 \\
\hline $\mathrm{Na}_{2} \mathrm{O}$ & 5,49 & 3.90 & 3.73 & 5.44 & 4.74 & 4,00 & 4.01 \\
\hline $\mathrm{K}_{2} \mathrm{O}$ & 5.41 & 4.67 & 4.57 & 3.56 & 4.21 & 4.32 & 4.33 \\
\hline $\mathrm{P}_{2} \mathrm{O}_{5}$ & 0.09 & 0.01 & 0.02 & 0.02 & 0.01 & 0,01 & 0.01 \\
\hline \multicolumn{8}{|c|}{ Trace elements (ppm) } \\
\hline $\mathrm{Cr}$ & 14 & N.D. & N.D. ${ }^{5}$ & 1 & 2 & 8 & 2 \\
\hline Co & N.A. & N.A. ${ }^{d}$ & N.A. & N.A. & N.A. & N.A. & N.A. \\
\hline $\mathrm{Sc}$ & 15.5 & 0.1 & 1.1 & 0.5 & 0.4 & 0.2 & 0.5 \\
\hline $\mathrm{Ni}$ & N.A. & N.A. & N.A. & N.A. & N.A. & N.A. & N.A. \\
\hline V & 3 & 1 & 1 & 1 & 2 & 4 & 3 \\
\hline Sr & 121 & 7 & 15 & 9 & 33 & 8 & 22 \\
\hline $\mathrm{Rb}$ & 139 & 293 & 638 & 840 & 649 & 444 & 707 \\
\hline $\mathrm{Ba}$ & 1534 & 20 & 70 & 37 & 16 & 18 & 24 \\
\hline Th & 14.9 & 8.1 & 52.8 & 13.5 & 22.2 & 23.3 & 37.2 \\
\hline U & 4.1 & 3.1 & 9.9 & 6.1 & 9.7 & 6.8 & 11.4 \\
\hline $\mathrm{Cs}$ & 1.8 & 0.9 & 4.2 & 3.4 & 2.4 & 2.2 & 2.8 \\
\hline $\mathrm{Zr}_{\mathrm{r}}$ & 1748 & 235 & 190 & 101 & 1018 & 537 & 917 \\
\hline $\mathrm{Nb}$ & 86 & 74 & 107 & 110 & 165 & 147 & 258 \\
\hline Y & 121 & 192 & 114 & 33 & 1307 & 260 & 405 \\
\hline $\mathrm{Hf}$ & 41.8 & 10.4 & 11.2 & 15.0 & 44.9 & 22.2 & 36.8 \\
\hline $\mathrm{Ta}$ & 3.6 & 3.7 & 11.5 & 18,3 & 9.2 & 8.3 & 12.3 \\
\hline La & 76.7 & 70.5 & 60.8 & 22.5 & 527.1 & 74.4 & 198.6 \\
\hline $\mathrm{Ce}$ & 185.9 & 154.4 & 150.3 & 60.9 & 1422.0 & 170.2 & 567.5 \\
\hline $\mathrm{Nd}$ & 105.8 & 654.0 & 42.7 & 19.5 & 679.4 & 70.4 & 259.7 \\
\hline $\mathrm{Sm}$ & 23.16 & 14.18 & 10.63 & 4.13 & 204.65 & 19.35 & 68.98 \\
\hline Eu & N.D. & 0.47 & 0.37 & 0.14 & 4.16 & 0.68 & 1.49 \\
\hline $\mathrm{Tb}$ & N.D. & N.D. & N.D. & 0.74 & 43.90 & 5.24 & 14.85 \\
\hline $\mathrm{Yb}$ & 14.06 & 11.07 & 18.29 & 7.11 & 52.24 & 21.83 & 34.86 \\
\hline Lu & 2.23 & 1.39 & 2.74 & 1.13 & 7.38 & 2.98 & 5.28 \\
\hline $\mathrm{Ga}$ & 37 & 47 & 35 & 47 & 46 & N.D. & 45 \\
\hline $\mathrm{Zn}$ & 182 & 94 & 19 & 23 & 1186 & 381 & 856 \\
\hline
\end{tabular}

"Shannon et al. (1997) describe techniques used in the analysis of RBG samples.

bSee text for further discussion.

'N.D., not detected.

${ }^{d}$ N.A., not analyzed. 
Table 6:

Table 6

Representative chemical analyses ${ }^{*}$ of granitic rocks of the ERB

\begin{tabular}{|c|c|c|c|c|c|c|c|c|c|c|}
\hline $\begin{array}{l}\text { Suite } \\
\text { Description } \\
\text { Sample } \\
\text { No. }\end{array}$ & $\begin{array}{l}\text { ERB } \\
\text { Outer } \\
\text { zone } \\
\text { ERB-15 }\end{array}$ & $\begin{array}{l}\text { ERB } \\
\text { Outer } \\
\text { zone } \\
\text { ERB-47 }\end{array}$ & $\begin{array}{l}\text { ERB } \\
\text { Outer } \\
\text { zone } \\
\text { ERB-2 }\end{array}$ & $\begin{array}{l}\text { ERB } \\
\text { Outer } \\
\text { zone } \\
\text { ERB-4 }\end{array}$ & $\begin{array}{l}\text { ERB } \\
\text { Outer } \\
\text { zone } \\
\text { ERB-38 }\end{array}$ & $\begin{array}{l}\text { ERB } \\
\text { Inner } \\
\text { zone } \\
\text { ERB-41 }\end{array}$ & $\begin{array}{l}\text { ERB } \\
\text { Inner } \\
\text { zone } \\
\text { ERB-36 }\end{array}$ & $\begin{array}{l}\text { ERB } \\
\text { Enclave } \\
\text { PQ-5 }\end{array}$ & $\begin{array}{l}\text { ERB } \\
\text { Enclave } \\
\text { ERB-50A }\end{array}$ & $\begin{array}{l}\text { ERB } \\
\text { Enclave } \\
\text { ERB-30 }\end{array}$ \\
\hline \multicolumn{11}{|c|}{ Major elements (wt\%) } \\
\hline $\mathrm{SiO}_{2}$ & 75.72 & 73.62 & 70.19 & 68.50 & 73.80 & 72.52 & 73.04 & 67.30 & 70.20 & 66.30 \\
\hline $\mathrm{TiO}_{2}$ & 0.20 & 0.20 & 0.37 & 0.33 & 0.12 & 0.23 & 0.22 & 0.52 & 0.37 & 0.60 \\
\hline $\mathrm{Al}_{2} \mathrm{O}_{3}$ & 12.19 & 12.64 & 13.34 & 13.79 & 13.00 & 13.23 & 12.60 & 13.78 & 13.47 & 14.15 \\
\hline FeOT & 1.66 & 1.75 & 2.57 & 2.52 & 1.25 & 1.95 & 1.83 & 3.36 & 2.73 & 4.41 \\
\hline $\mathrm{MnO}$ & 0.02 & 0.03 & 0.05 & 0.05 & 0.02 & 0.04 & 0.04 & 0.05 & 0.06 & 0.08 \\
\hline $\mathrm{MgO}$ & 0.18 & 0.20 & 0.41 & 0.46 & 0.12 & 0.53 & 0.50 & 0.93 & 0.70 & 0.98 \\
\hline $\mathrm{CaO}$ & 0.80 & 0.88 & 1.58 & 1.40 & 0.76 & 1.11 & 1.05 & 2.20 & 1.78 & 2.34 \\
\hline $\mathrm{Na}_{2} \mathrm{O}$ & 3.02 & 3.18 & 3.33 & 3.40 & 3.52 & 3.19 & 3.13 & 4.36 & 3.61 & 4.27 \\
\hline $\mathrm{K}_{2} \mathrm{O}$ & 5.36 & 5.74 & 5.88 & 5,83 & 5.66 & 5.19 & 5.03 & 2.88 & 4.11 & 3.16 \\
\hline $\mathrm{P}_{2} \mathrm{O}_{5}$ & 0.05 & 0.05 & 0.11 & 0.09 & 0.00 & 0.07 & 0.07 & 0.14 & 0.09 & 0.27 \\
\hline \multicolumn{11}{|c|}{ Trace elements (ppm) } \\
\hline $\mathrm{Cr}$ & 3 & 3 & 5 & 6 & 3 & 3 & 5 & 15 & 7 & 15 \\
\hline $\mathrm{Co}$ & 1.2 & 1.7 & 3.3 & 3.0 & 0.8 & 2.7 & 3.3 & 6.9 & 4.5 & 7.6 \\
\hline $\mathrm{Sc}$ & 2.7 & 3.1 & 6.0 & 7.1 & 0.1 & 4.6 & 4.8 & 7.4 & 5.4 & 6.0 \\
\hline $\mathrm{Ni}$ & N.A. & N.A. & N.A. ${ }^{b}$ & N.A. & N.A. & N.A. & N.A. & N.A. & N.A. & N.A. \\
\hline $\mathrm{v}$ & 11 & 16 & 24 & N.A. & N.A. & 28 & 29 & N.A. & N.A. & N.A. \\
\hline $\mathrm{Sr}$ & 51 & 62 & 132 & 111 & 58 & 105 & 99 & 200 & 145 & 126 \\
\hline $\mathrm{Rb}$ & 159 & 223 & 176 & 264 & 289 & 210 & 222 & 174 & 203 & 234 \\
\hline $\mathrm{Ba}$ & 237 & 401 & 1040 & 696 & 325 & 632 & 557 & 531 & 584 & 310 \\
\hline Th & 19.1 & 22.3 & 15.4 & 20.5 & 26.1 & 16.6 & 16.6 & 9.4 & 11.8 & 11.2 \\
\hline $\mathrm{U}$ & 1.7 & 2.6 & 1.8 & 3.4 & 4.5 & 3.8 & 3.7 & 2.0 & 1.8 & 3.2 \\
\hline $\mathrm{Cs}$ & 1.9 & 2.1 & 2.2 & 5.2 & 2.9 & 7.0 & 6.9 & 4.2 & 2.1 & 5.4 \\
\hline $\mathrm{Zr}$ & 78 & 71 & 124 & 262 & 197 & 63 & 71 & 282 & 257 & 323 \\
\hline $\mathrm{Nb}$ & 15 & 6 & 18 & 20 & 11 & 14 & 15 & 16 & 17 & 19 \\
\hline $\mathrm{Y}$ & 47 & 55 & 54 & 100 & 46 & 31 & 24 & 39 & 67 & 36 \\
\hline Hf & 8.0 & 6.5 & 10.0 & 8.8 & 7.3 & 6.3 & 6.3 & 8.7 & 7.5 & 9.2 \\
\hline $\mathrm{Ta}$ & 0.5 & 0.8 & 1.0 & 2.6 & 0.7 & 1.4 & 1.4 & 0.5 & 1.1 & 0.9 \\
\hline $\mathrm{La}$ & 87.4 & 75.1 & 67.8 & 68.1 & 49.2 & 37.6 & 38.0 & 51.7 & 64.0 & 42.6 \\
\hline $\mathrm{Ce}$ & 202.6 & 168.4 & 160.8 & 149.0 & 112.3 & 84.5 & 90.1 & 98.1 & 131,4 & 88.8 \\
\hline $\mathrm{Nd}$ & 80.0 & 71.1 & 71.2 & 63.9 & 49.9 & 36.2 & 37.6 & 38.9 & 52.9 & 37.1 \\
\hline $\mathrm{Sm}$ & 14.05 & 12.10 & 12.96 & 14.20 & 9.91 & 6.45 & 6.69 & 7.88 & 10.80 & 8.25 \\
\hline $\mathrm{Eu}$ & 0.90 & 0.96 & 1.77 & 1.25 & 0.71 & 0.79 & 0.81 & 1.51 & 1.13 & 0.91 \\
\hline $\mathrm{Tb}$ & 1.80 & 1.87 & 1.86 & 2.47 & 1.15 & 0.80 & 0.94 & 1.13 & 1.61 & 1.15 \\
\hline $\mathrm{Yb}$ & 4.72 & 5.67 & 6.17 & 10.50 & 4.52 & 4.11 & 3.87 & 3.46 & 5.57 & 4.22 \\
\hline $\mathrm{Lu}$ & 0.62 & 0.77 & 0.84 & 1.44 & 0.57 & 0.66 & 0.62 & 0.50 & 0.79 & 0.55 \\
\hline $\mathrm{Ga}$ & 16 & 19 & 18 & 19 & 18 & 17 & 17 & 17 & 16 & 19 \\
\hline $\mathrm{Zn}$ & 52 & 42 & 59 & 59 & 44 & 38 & 43 & 75 & N.A. & 110 \\
\hline
\end{tabular}

"ICP spectrometry techniques were used to analyze major elements in whole-rock samples of the ERB (University of Texas-Austin and X-ray Assay Laboratories, Toronto). Trace element analyses for ERB samples were obtained using a combination of techniques including ICP, X-ray fluorescence spectrometry ( $\mathrm{X}$-ray Assay Laboratories, Toronto), and neutron activation (Oregon State University). For elements determined by more than one method, results by the most accurate method are reported.

${ }^{b}$ N.A., not analyzed. 
Table 7:

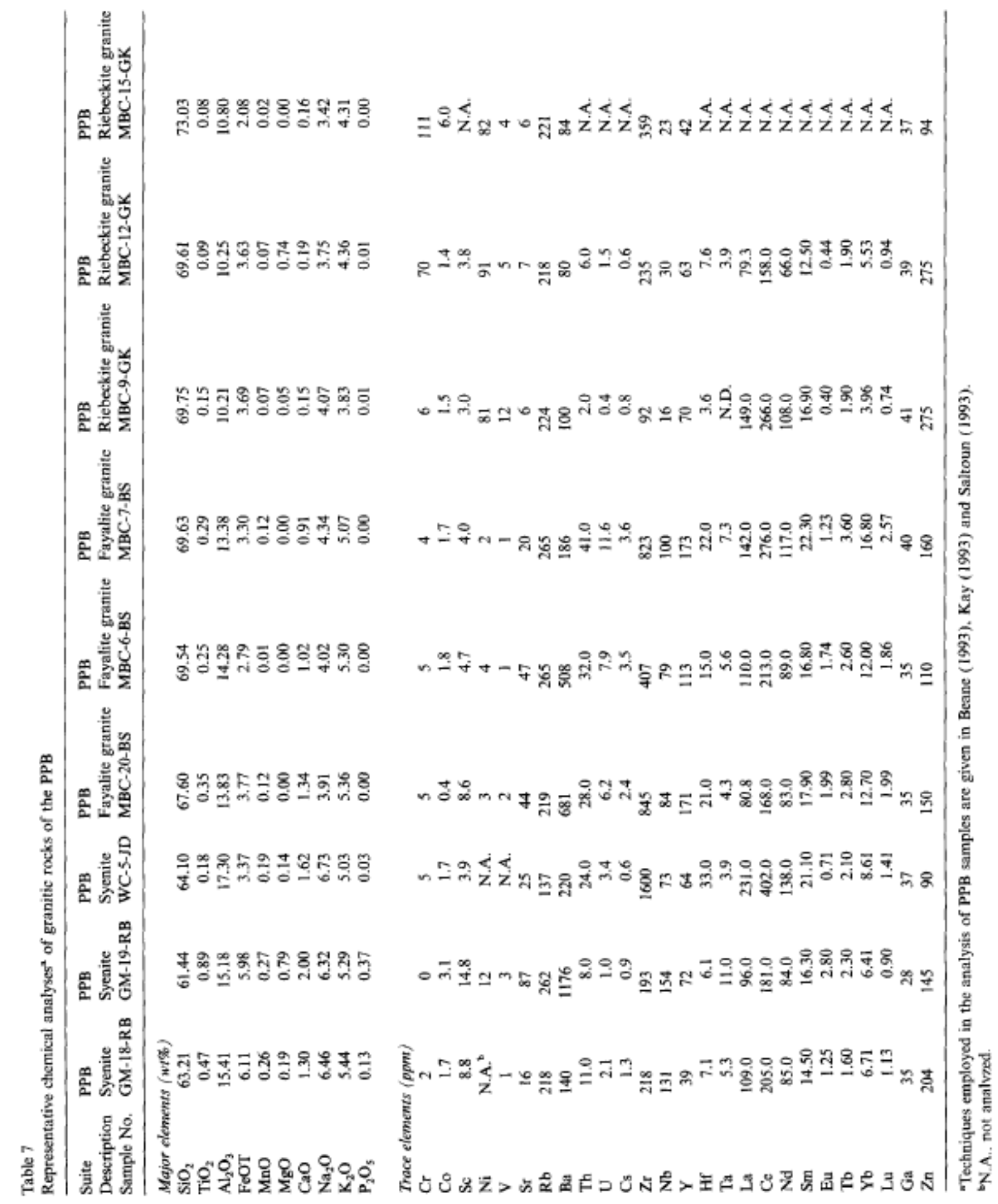


Figure 9:

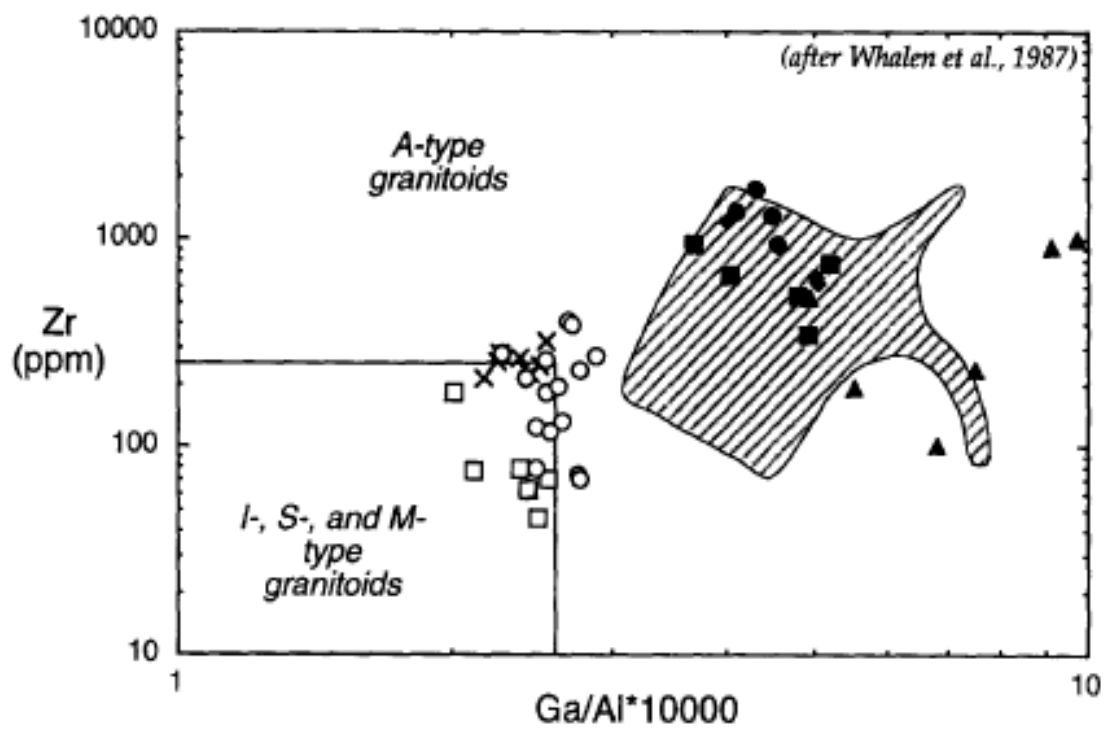

Fig. 9. $\mathrm{Zr}$ (ppm) and $\mathrm{Ga} / \mathrm{Al} \mathbf{1}^{*} 10000$ in bulk-rock samples of the RBG. ERB and sodic PPB; symbols and field as in Fig. 5. Fields for A-, I-, S- and M-type granitoids from Whalen et al. (1987).

Figure 10:

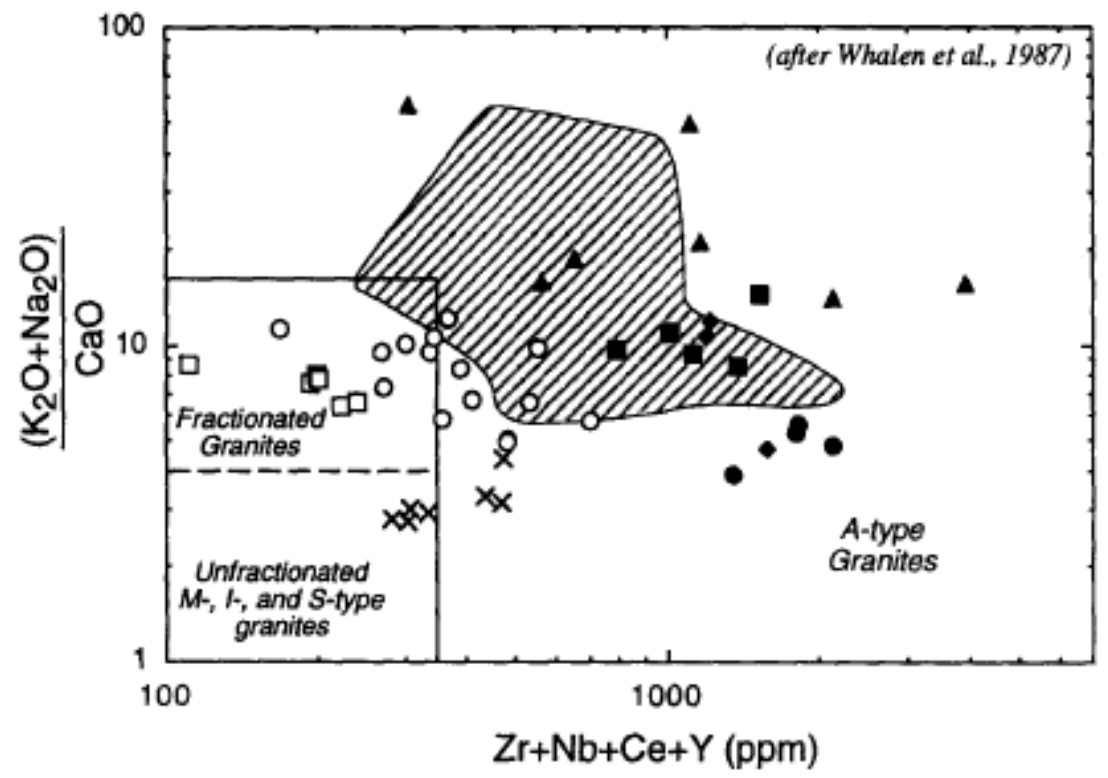

Fig. 10. $\left(\mathrm{K}_{2} \mathrm{O}+\mathrm{Na}_{2} \mathrm{O}\right) / \mathrm{CaO}$ and $\mathrm{Zr}+\mathrm{Nb}+\mathrm{Ce}+\mathrm{Y}(\mathrm{ppm})$ in bulk-rock samples of the RBG, ERB and sodic PPB; symbols and field as in Fig. 5. Fields for fractionated granites, unfractionated M-, I- and S-type granites, and A-type granites from Whalen et al. (1987). 
Figure 11:

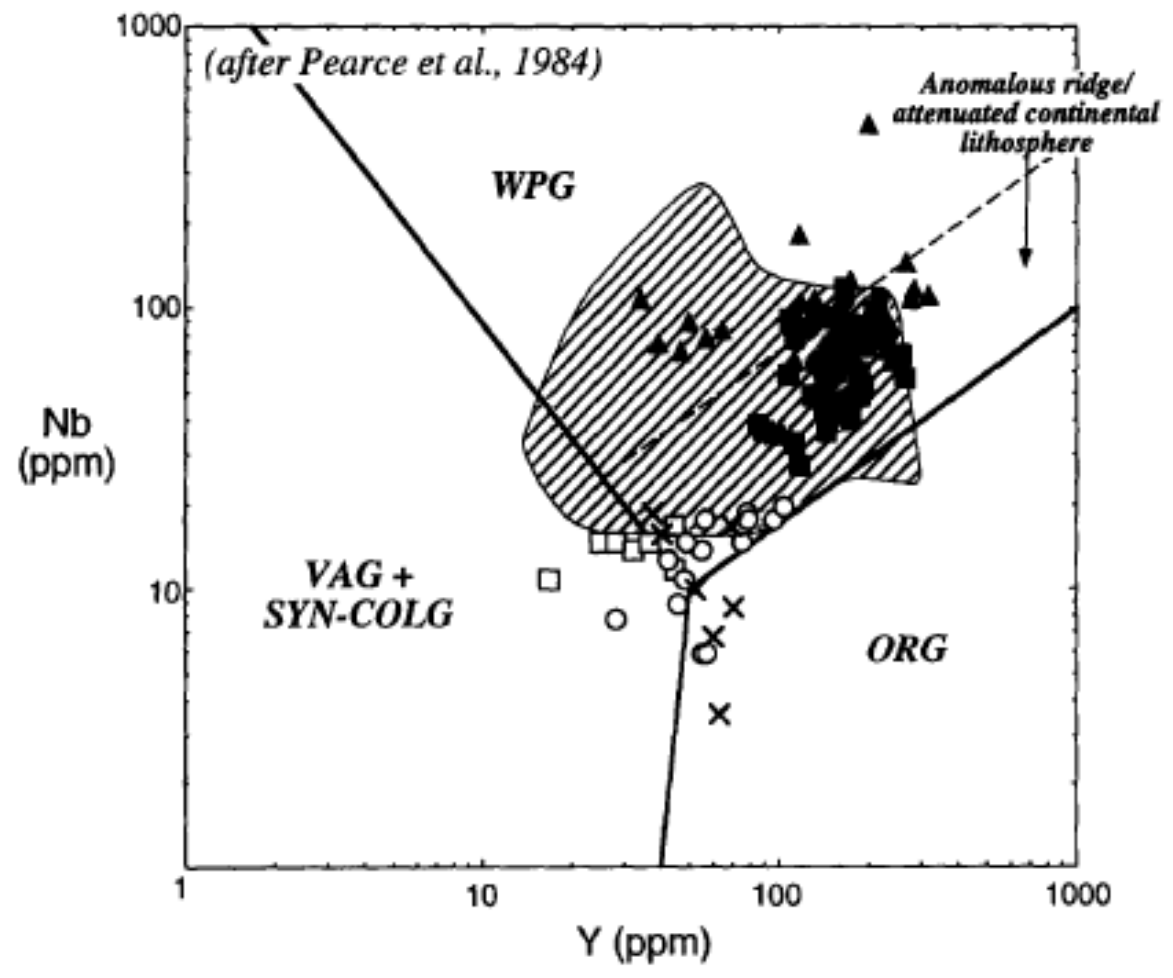

Fig. 11. Nb and Y (ppm) in bulk-rock samples of the RBG, ERB and sodic PPB; symbols and field as in Fig. 5. ORG, Oceanic ridge granites; VAG, volcanic arc granites; SYN-COLG, syn-collision granites; and WPG, within-plate granites [after Pearce et ai. (1984)]. 
Figure 12:

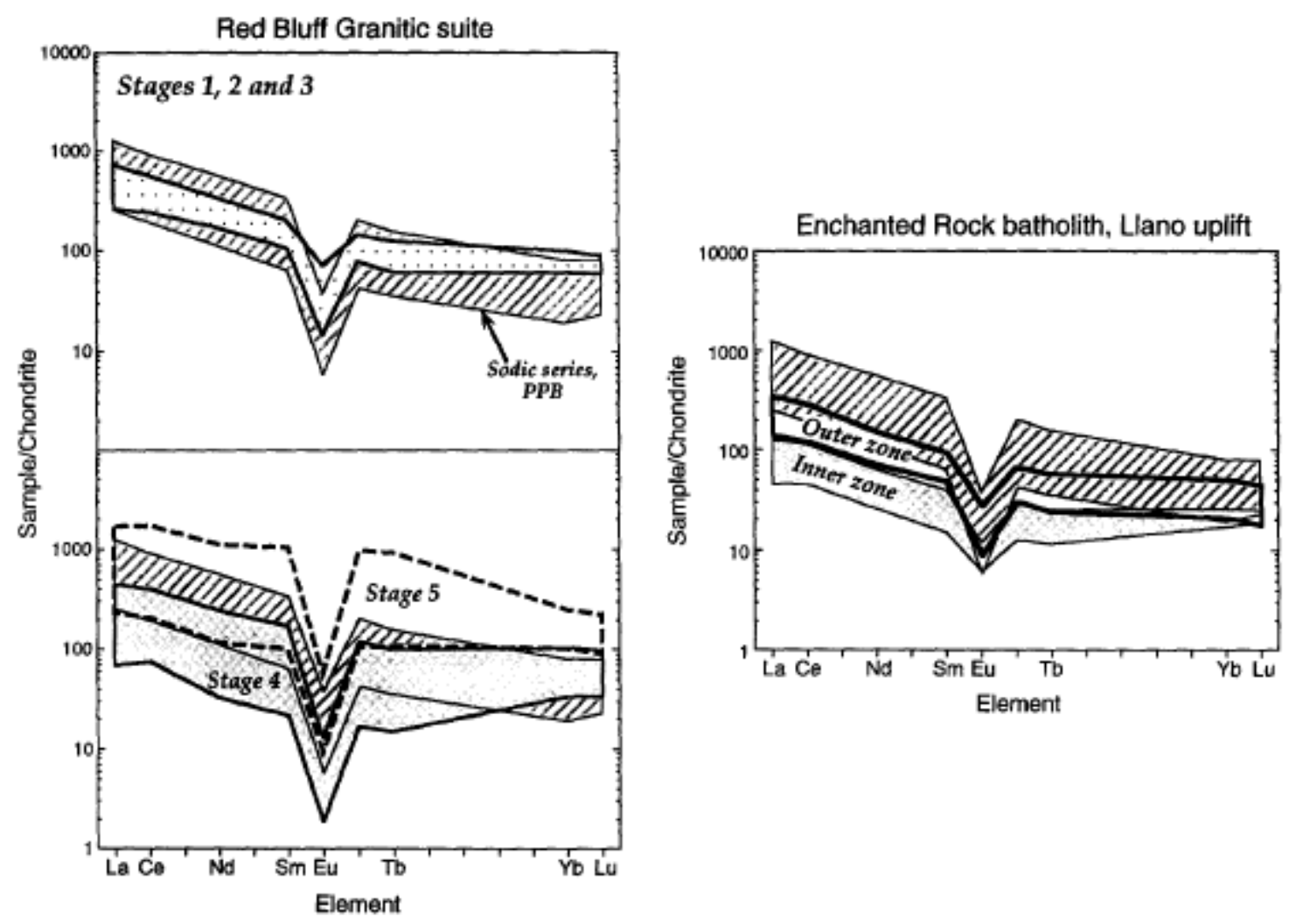

Fig. 12. Rare earth profiles for RBG and ERB bulk-rock samples; ruled field for PPB sodic series rocks is shown on all panels for comparison. 
Figure 13:

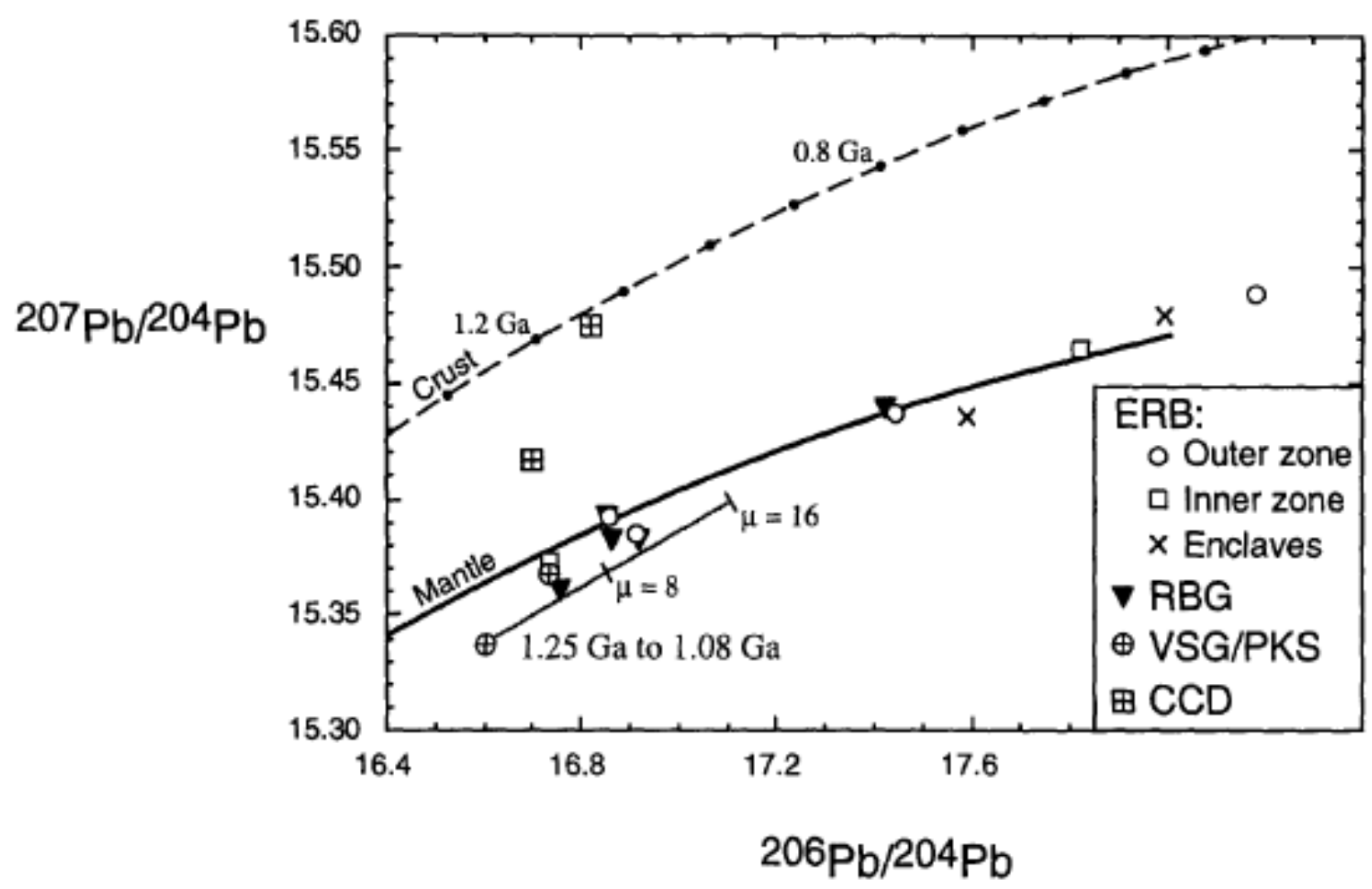

Fig. 13. Lead isotopic compositions for the ERB and RBG; data are from Table 8. Dashed curve is the Stacey and Kramers (1975) model curve for average crust (dots are at intervals of $0.10 \mathrm{Ga}$ ). Solid curve is from Zartman and Doe (1981) model mantie; our feldspar data cluster near a mantle model age of $\sim 1.0 \mathrm{Ga}$. Other Llano rocks illustrated include $\sim 1.25 \mathrm{Ga}$ tectonized granitic rocks (Valley Spring Gneiss and orthogneiss within Packsaddle Schist, VSG/PKS) and rocks of the Coal Creek Domain (CCD) (Roback et al., 1995). 
Table 8:

Table 8

$\mathrm{Sm}-\mathrm{Nd}$ and $\mathrm{Pb}$ isotopic data

\begin{tabular}{|c|c|c|c|c|c|c|c|c|}
\hline Sample & $\operatorname{Sm}(p p m)^{a}$ & Nd $(p p m)^{a}$ & ${ }^{147} \mathrm{Sm} /{ }^{144} \mathrm{Nd}^{e}$ & ${ }^{143} \mathrm{Nd} /{ }^{144} \mathrm{Nd}^{b}$ & $\epsilon_{\text {Nat: }}^{f_{1}}$ & ${ }^{2000} \mathrm{~Pb} /{ }^{204} \mathrm{~Pb}^{d}$ & ${ }^{20}{ }^{5} \mathrm{~Pb} /{ }^{204} \mathrm{~Pb}$ & ${ }^{205} \mathrm{~Pb} /{ }^{204} \mathrm{~Pb}^{4}$ \\
\hline \multicolumn{9}{|l|}{$E R B$} \\
\hline ERB-4 wr ${ }^{e}$ & 16.89 & 87.03 & 0.1174 & $0.512297 \pm 5$ & 4.31 & 18.184 & 15.489 & 38.002 \\
\hline ERB-4 $\mathrm{fs}^{\mathrm{r}}$ & & & & & & 16.916 & 15.385 & 36.537 \\
\hline ERB-15 wr & 14.33 & 82.94 & 0.1045 & $0.512149 \pm 4$ & 3.21 & 17,446 & 15.438 & 37.694 \\
\hline ERB-15 fs & & & & & & 16.860 & 15.393 & 36.562 \\
\hline ERB-41 wr & 6.02 & 34.02 & 0.1070 & $0.512192 \pm 6$ & 3.69 & 17,826 & 15.465 & 37.057 \\
\hline ERB-41 f3 & & & & & & 16.736 & 15.373 & 36.332 \\
\hline ERB-S0A wr & 10.71 & 59.18 & 0.1095 & $0.512184 \pm 5$ & 3.20 & 17.995 & 15.480 & 38.133 \\
\hline PQ-5 wr & 7.86 & 42.86 & 0.1109 & $0.512170 \pm 4$ & 2.72 & 17.590 & 15.437 & 37.824 \\
\hline \multicolumn{9}{|l|}{$R B G$} \\
\hline FM-133 fs & & & & & & 16.865 & 15.382 & 36.594 \\
\hline FM-146 fs & & & & & & 16.918 & 15.382 & 36.553 \\
\hline FMTM-2A fs & & & & & & 16.855 & 15.392 & 36.561 \\
\hline $\mathrm{FM}-532 \mathrm{fs}$ & & & & & & 16.760 & 15.360 & 36.399 \\
\hline FM- $623 \mathrm{fs}$ & & & & & & 17.425 & 15.439 & 37.106 \\
\hline
\end{tabular}

'Uncertainty $=\sim 0.5 \%$.

bUncertainty is given at the two sigma level for individual measurements. Reproducibility is $\sim 0.000012(2 \sigma)$ based on replicate analyses of $\mathrm{CITnNd} \beta$. Nd isotopic compositions were corrected for mass fractionation using an exponential fractionation law and normalized to ${ }^{106} \mathrm{Nd} /{ }^{144} \mathrm{Nd}=0.7219$.

${ }^{\mathrm{A} A g e}$ of $1.08 \mathrm{Ga}$ (Walker, 1992).

${ }^{4} \mathrm{~Pb}$ isotopic ratios are corrected for fractionation of $0.11 \% \pm 0.03 \%$ /amu based on replicate analyses of NBS 981 . Total uncertainty for $\mathrm{Pb}$ isotopic ratios is better than $\pm 0.1 \%(2 \sigma)$.

"Wr, Whole rock.

${ }^{\mathrm{f}} \mathrm{s}$, Hand-picked, HF-leached potassium feldspar. 
Figure 14:

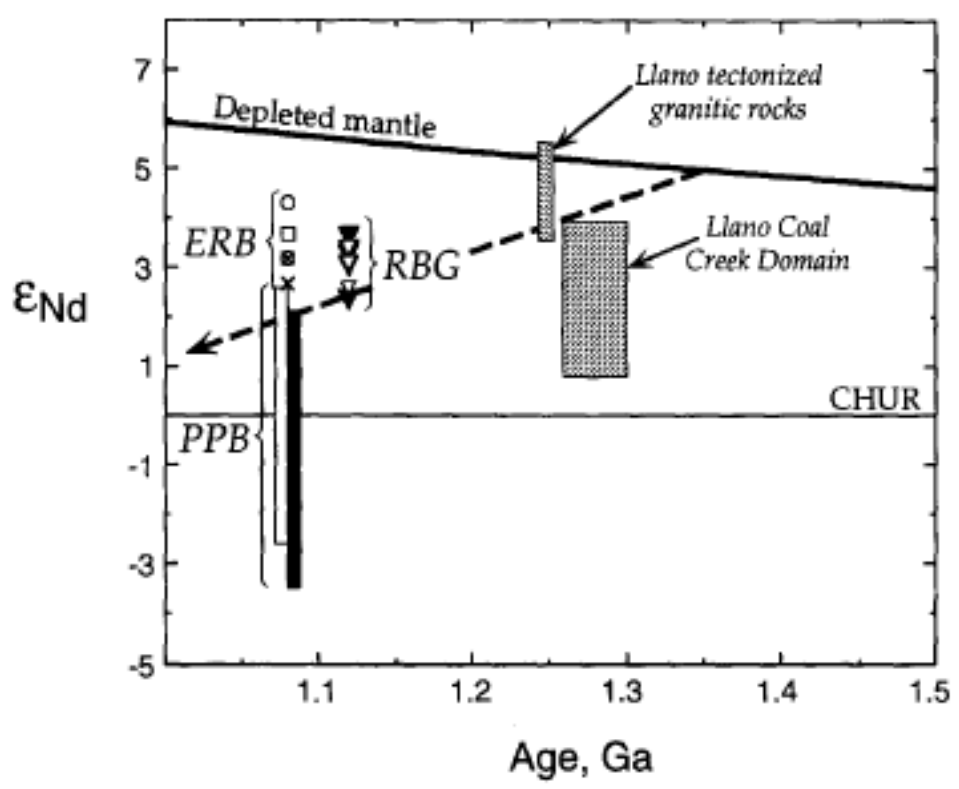

Fig, 14. Initial $\epsilon_{\mathrm{NA}}$ versus age diagram for Precambrian rocks of the PPB, RBG and ERB. CHUR, chondritic uniform reservoir (bulk earth) isotopic evolution. Depleted mantle evolution line of DePaolo (1981). Dashed vector shows the evolution of crust extracted from depleted mantle sources at $1.35 \mathrm{Ga}$. PPB (Douglass and Smith, 1993): solid bar, mafic rocks; open bar, sodic granitoids. RBG (Patchett and Ruiz, 1989): $\nabla$, mafic rocks; $\mathbf{\nabla}$, granitoids. Additional data for mafic dikes from Cameron (1995, personal communication) are not plotted, but are within the range exhibited by Patchett and Ruiz's data. ERB (Table 8, this study): symbols as in Fig. 13. Data for Llano $\sim 1.25 \mathrm{Ga}$ tectonized granitic rocks and the Coal Creek Domain are from Roback et al. (1995). Although omitted here for simplicity, $\epsilon_{\mathrm{Na}}$ data for Llano post-tectonic intrusives from Patchett and Ruiz (1989) lie within the range exhibited by the ERB samples shown here. 
Figure 15:

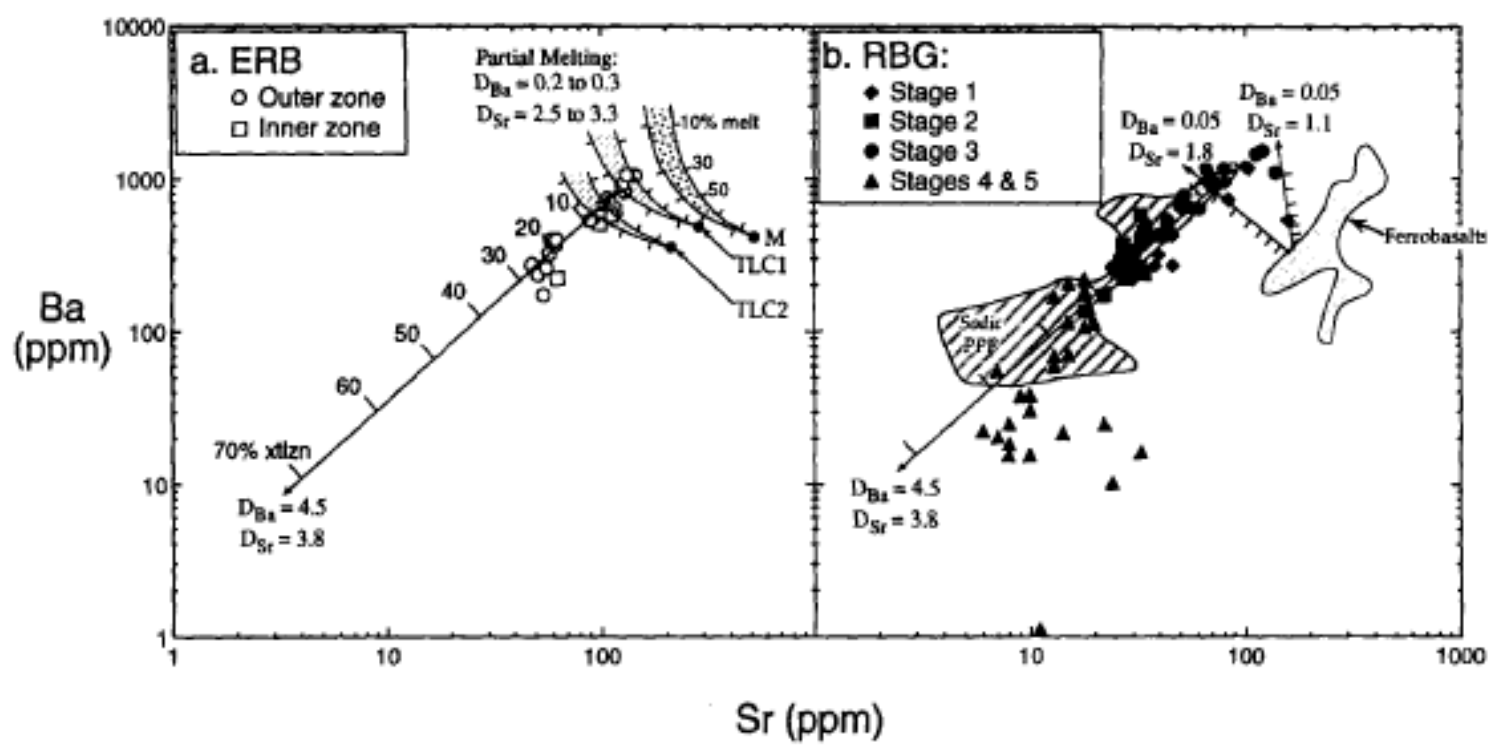

Fig. 15. Log Ba versus log Sr contents in (a) ERB and (b) RBG and sodic PPB rocks; field and symbols as in Fig. 5. Both panels include vectors for fractional crystallization involving different bulk distribution coefficients ( $D$ values). Tick marks on fractionation vectors are given at $10 \%$ increments (up to $70 \%$ ) of crystallization. (a) Curves illustrate trends in $\mathrm{Ba}$ and $\mathrm{Sr}$ during partial melting of lower crust. TLCl and TLC2 are the mean and median compositions (tonalitic), respectively, of hundreds of analyses for postArchean rocks of granulite facies terrains, and $\mathrm{M}$ is the mean composition (mafic) of hundreds of analyses for granulite facies xenoliths [ef Table II in Rudnick and Presper (1990)]. Tick marks on melting curves are given at 10,30,50,70 and 90\% melting. Bulk $D_{s}$ used in the partial melting models ranged from 0.2 to 0.3 for $\mathrm{Ba}$, and from 2.5 to 3.3 for $\mathrm{Sr}$. (b) The range in $\mathrm{Ba}$ and $\mathrm{Sr}$ exhibited by sodic PPB rocks, and mafic (ferrobasaltic) dikes of the RBG. 
Figure 16:

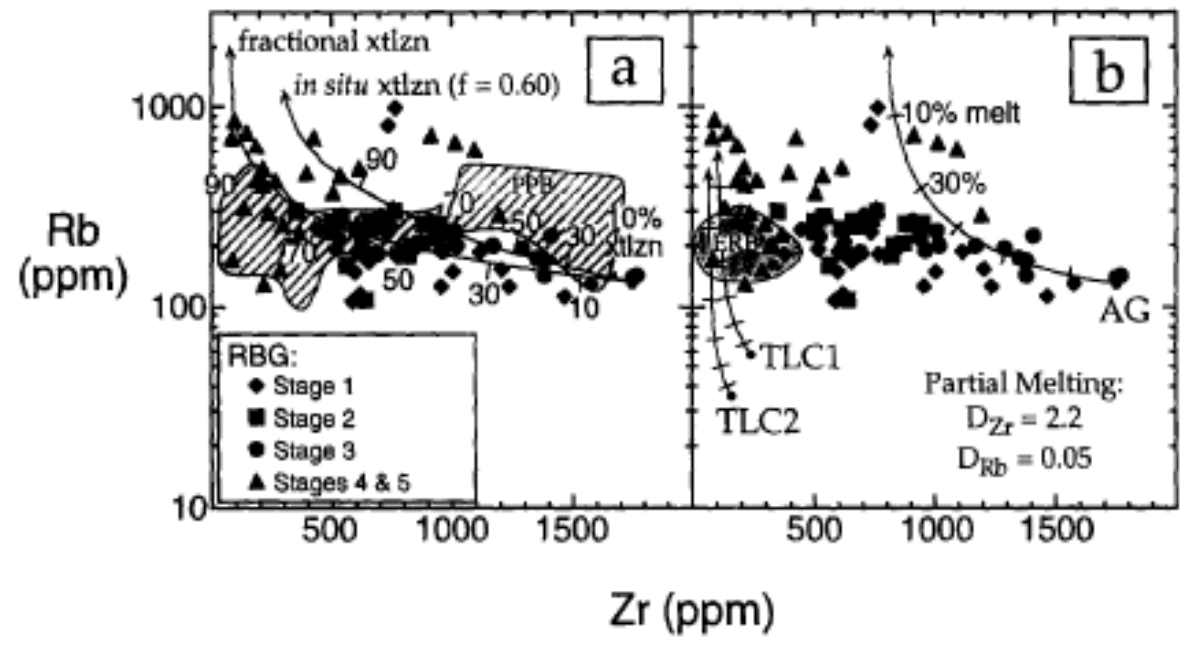

Fig. 16. Log Rb versus $\mathrm{Zr}$ contents in the RBG and models for erystallization and partial melting processes. (a) Calculated trends for fractional crystallization and 'in situ' or inefficient crystallization of a syenitic parent with $40 \%$ trapped liquid ( $60 \%$ of the melt was extracted). Bulk $D$ for $\mathrm{Rb}$ was 0.4 and for $\mathrm{Zr} 2.2$, based on major element mass balance calculations (Shannon, 1994) and zircon solubility data (see Shannon et al., 1997). Ruled field, sodic PPB compositions. (b) Calculated trends for partial melting of high-Zr alkali gabbro (AG; Shannon and Barnes, unpublished data) and tonalitic [TLC1 and TLC2, from Rudnick and Presper (1990), as in Fig. 15] sources with no residual micas. Bulk $D$ for $\mathrm{Rb}$ was 0.05 and for $\mathrm{Zr} 2.2$. Shaded field, ERB compositions. Mafic xenolith compositions (M, cf Fig. 15) are not used as sources here because they have even lower Rb and Z $\mathrm{r}$ contents than tonalitic compositions. 